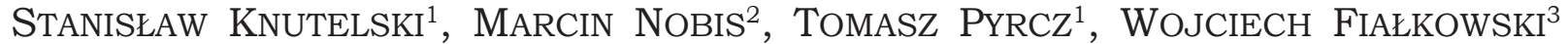

${ }^{1}$ Instytut Zoologii i Badań Biomedycznych

Uniwersytet Jagielloński

Gronostajowa 9, Kraków

${ }^{2}$ Instytut Botaniki

Uniwersytet Jagielloński

Gronostajowa 3, Kraków

${ }^{3}$ Instytut Nauk o Środowisku

Uniwersytet Jagielloński

Gronostajowa 7, Kraków

E-mail: s.knutelski@uj.edu.pl

\title{
ZASOBY INFORMACJI O RÓŻNORODNOŚCI BIOTYCZNEJ EUKARYOTA W KOLEKCJACH PRZYRODNICZYCH UNIWERSYTETU JAGIELLONNSKIEGO
}

\section{DZIEJE POZYSKIWANIA INFORMACJI \\ O RÓŻNORODNOŚCI BIOTYCZNEJ I GROMADZENIA ZBIORÓW \\ PRZYRODNICZYCH W UNIWERSYTECIE JAGIELLOŃSKIM}

Bogate i zróżnicowane zbiory przyrodnicze, wraz ze specjalistyczną literatura $z$ różnych epok, sa nieoceniona baza naukowa i kulturowo-historyczna stanowiaca podstawę do nauczania na najwyższym światowym poziomie i bezcenne dziedzictwo przeszłości, $z$ którego korzystały i będa korzystać kolejne pokolenia. Już w XV w. w ówczesnej Akademii Krakowskiej rozumiano wartość najróżnorodniejszych kolekcji, a wraz $z$ biegiem czasu zaczęło się ich stopniowe powiększanie. Zaczęło przybywać przyrządów astronomicznych i geodezyjnych oraz najwcześniejszych kolekcji numizmatycznych, makat i obrazów. Od XVI w. rozwija się "camera raritatis", czyli zbiór rozmaitych osobliwości (KÖHLER 1999). Wiedzę o minerałach, roślinach i zwierzętach wykładano w krakowskiej Alma Mater już w XV w. na wydziale filozoficznym i lekarskim. Od 1609 r. istniała katedra botaniki lekarskiej (ufundowana przez Jana Zemełkę w 1602 r.), a nauka botaniki na potrzeby medycyny wykładana była już od końca XVI w.
Udokumentowane początki pozyskiwania danych o różnorodności biotycznej i gromadzeniu zbiorów muzealnych najstarszej polskiej uczelni sięgają drugiej połowy XV w. Wtedy pojawiaja się rękopiśmienne przekazy dotyczace wiadomości o roślinach i zwierzętach oraz inwentarze historycznie cennych przedmiotów. Były to tzw. glossy lub słowniczki, obejmujace zestawienia łacińskich nazw minerałów, roślin i zwierząt przydatnych do sporządzania leków (JURA 1992). $\mathrm{Na}$ marginesach niektórych kartek glossów (znajduja się obecnie w Bibliotece Jagiellońskiej), obok nazw naukowych, widnieja także nazwy polskie roślin i zwierzat, przeważnie ludowe (nazewnictwo wernakularne). Pierwszy oryginalny polski słowniczek pod nazwa "Antibolomenon" (lub „Antidotarium”) powstał w Krakowie w 1472 r. Jest to dzieło Jana Stanko (znany także jako Johannes Stanconis), profesora medycyny Akademii Krakowskiej i przyrodoznawcy (JURA 1992). Liczące 540 stron in folio opracowanie, ujęte w 3 częściach, jest jednocześnie kompendium sztuki medycznej, praktyk leczniczych i aptekarskich oraz ogromna, jak na owe czasy, encyklopedią minerałów, roślin i zwierząt. Oprócz informacji o dawnych nazwach chorób, częściach ciała człowieka czy napojach

Słowa kluczowe: Eukaryota, kolekcje przyrodnicze, różnorodność biotyczna, Uniwersytet Jagielloński, zasoby informacji *Artykuł powstał dzięki wsparciu finansowemu z projektu POPC.02.03.01-00-0081/19 „Integracja i mobilizacja danych o różnorodności biotycznej Eukaryota w zasobach polskich instytucji naukowych" (IMBIO). 
i pokarmach stosowanych w ówczesnym lecznictwie, zawiera ogromne bogactwo treści przyrodniczych. „Antidotarium” obejmuje 20000 synonimów łacińskich, niemieckich, greckich i arabskich, wśród których znalazło się też ok. 2000 synonimów polskich, co pozwala uznać Jana Stanko za prekursora polskiego nazewnictwa przyrodniczego. Autor wymienia ogromna, jak na owe czasy, liczbe 523 gatunków roślin, w tym 90 zagranicznych i 433 krajowych. Ostatnia część dzieła, zawierajacca spis zwierzat krajowych „nie majacych znaczenia w medycynie", obejmuje 219 gatunków, prawie wyłącznie krajowych, w tym 44 gatunki ssaków, 88 gatunków ptaków i, co ciekawe, 2 gatunki gąbek, które wówczas były powszechnie uważane za rośliny. Według Józefa Rostafińskiego, wybitnego polskiego botanika, który opracował i wydał w 1900 r. część botaniczna dzieła $z$ rękopisu należacego do archiwum kapitulnego na Wawelu, „Antidotarium” jest wielkim katalogiem flory i fauny oraz najobszerniejszym i najdoskonalszym dziełem średniowiecznej Europy, które wniosło ogromny wkład w rozwój nauk przyrodniczych, a Jan Stanko jest najwybitniejszym przyrodnikiem europejskim pomiędzy Albertem Wielkim a Konradem Gesnerem (RosTAFIŃSKI 1900). Szkoda jednak, że oddziaływanie tak ogromnego i znaczacego dzieła profesora Stanko miało niewielki wpływ na dalszy rozwój nauk przyrodniczych i nigdy nie zostało wydrukowane, pozostało $\mathrm{w}$ rękopisie.

Kiedy w Europie zaczyna się upowszechnianie tworzenia zielników $z$ zasuszonych roślin, w pierwszej połowie XVI w. pojawiają się w Krakowie, wydawane już drukiem, tzw. herbaria, czyli spisy ziół, krzewów, drzew, zwierząt i minerałów stosowanych w ówczesnej medycynie (JURA 1992). W 1534 r. zostaje wydrukowany herbarz "O ziołach $i$ mocy ich" (uznawany za najstarszy w Polsce), autorstwa Stefana Falimirza (lub Falimierza), botanika i lekarza, dworzanina wojewody podolskiego Jana Tęczyńskiego. Ten pierwszy zielnik w języku polskim jest jednocześnie pierwsza polska encyklopedia przyrodniczo-lekarska, obejmująca bardzo bogaty zasób terminów specjalistycznych. Księga ta nie posiada właściwie ogólnego tytułu, a tylko dwanaście nagłówków zawartych na karcie tytułowej, $z$ których pierwszy utarł się jako tytuł. Dzieło Falimirza wyróżnia się spośród ówcześnie wydawanych książek swoją objętością (liczy ok. 900 stron, 109 arkuszy) i obfitościa ilustracji (ponad 550). Składa się z pięciu części posiadających odrębne liczbowanie kart i sygnowanie składek, a pierwsza $z$ nich jest część botaniczna. W czwartej części wymienionych jest 138 taksonów zwierzat krajowych. Nie jest to jednak tylko samo nazewnictwo, ale przedstawiono tam także krótkie opisy zwierząt i kilka prymitywnych ilustrujacych je rycin. Zatem sa to pierwsze informacje dotyczace morfologii zwierząt Polski. Falimirz wykazuje szczególną wiedzę w zakresie fauny ryb krajowych i troskę o nie. Ubolewa, że nie sa badane: „W Polsce mieszkamy, potrzeba jest abyśmy polskich ryb obyczaje wiedzieli, gdyż ich ustawicznie używamy” i przewiduje, że: „wygina, jeżeli ich bliżej nie poznamy”. Wobec tego, możemy go także uznać za jednego $z$ pionierów ochrony zwierząt w Polsce. W 1542 r. zostaje wydana przeróbka tego dzieła pt. „O ziołach tutecznych $i$ zamorskich $i$ o mocy ich, a $k$ temu ksiegi lekarskie", autorstwa Hieronima Spiczyńskiego, pisarza-botanika i lekarza królewskiego.

Najsłynniejszym jednak dziełem $z$ tej kategorii jest dwutomowa, ilustrowana encyklopedia $z$ zakresu botaniki i medycyny, pt. „Herbarz Polski to jest o przyrodzeniu ziót $i$ drzew rozmaitych $i$ inszych rzeczy do lekarstw należacych ksiegi dwoje", napisana przez Marcina $z$ Urzędowa w latach 15431553, a wydana w Krakowie dopiero w 1595 r. W opracowaniu tym jest rownież wiele informacji o zwierzętach, wraz $z$ elementami zoologii stosowanej (JURA 1992). Autor zachęca np. do hodowli czerwca Porphyrophora polonica (Linnaeus, 1758), który do końca XVII w. miał w Polsce duże znaczenie gospodarcze, albowiem wytwarzano $z$ niego ceniony i bardzo trwały, czerwony barwnik zwany koszenila.

Wybitnym i unikatowym w skali Europy dziełem ówczesnego okresu był również herbarz Szymona Syreńskiego (Syreniusza), lekarza, botanika, profesora i wybitnego naukowca Akademii Krakowskiej. Będacy dziełem jego życia „Zielnik”, nad którym pracował ponad 30 lat, został wydany dopiero po śmierci autora w 1613 r. w Krakowie. Ten niepowtarzalny herbarz, liczacy 1584 strony i zawierajacy opisy 765 taksonów roślin, znanych i użytkowanych w środkowej oraz południowej Europie, stanowi źródło pierwszych historycznych danych dotyczacych flory tego regionu. Warto tu podkreślić, że Zielnik Syreniusza wydała własnym sumptem Anna Wazówna (1568-1625), córka Jana III Wazy, która jest nazywana królowa polskiej botaniki. Anna nie tylko sprawowała mecenat nad działalnościa naukowa $z$ dziedziny botaniki i medycyny, ale sama pasjonowała się botanika i przyrodolecznictwem, zbierała rośliny, badała ich właściwości lecznicze, a nawet urządziła sobie w tym celu laboratorium i utworzyła pierwszy w Polsce zielnik $z$ zasuszonych roślin. Zielnik ten był przechowywany w zbiorach Radziwiłłów w Nieświeżu, jednak w czasie II wojny światowej został zniszczony. 
Z nadejściem XVII w. przestają być wydawane herbarze, a nieliczne i dowolne informacje, nie mające znaczenia naukowego, np. o zwierzętach, ukazuja się jedynie w opracowaniach łowiecko-gospodarskich lub rozprawach historyków (JURA 1992). Dla przykładu, w kronice Długosza dowiadujemy się, że szarańcza nawiedziła kilka województw południowych, „a jest to owad na palec długi $z$ głowa nietoperza". Wówczas Kraków chyli się ku upadkowi, a w Akademii Krakowskiej następuje regres w rozwoju nauk przyrodniczych. Podobnie jest w pierwszej połowie XVIII w. u schyłku naszej państwowości, kiedy Kraków dostaje się pod zabór austriacki, a nikłe wiadomości przyrodnicze, przeważnie o charakterze encyklopedycznym, przekazywane sa tylko przez profesorów medycyny na kursach historii naturalnej. $Z$ tego okresu warto odnotować tylko jeden fakt gromadzenia osobliwości przyrodniczych ziemi krakowskiej przez biskupa Kajetana Sołtyka. Dopiero w drugiej połowie XVIII w., a dokładnie w 1777 r., przeprowadzona przez Hugona Kołłataja reforma, zwana reforma kołłątajowska, zapowiada zwrot, wprowadzając do badań i edukacji metody empiryczne. Kluczowa rolę odegrało w tym utworzenie w 1780 r. Katedry Chemii i Historii Naturalnej, czynnej od 1783 r. w Kolegium Fizycznym Akademii Krakowskiej. Jej zakładami pomocniczymi miały być: Ogród Botaniczny, Gabinet Chemiczny i Gabinet Historii Naturalnej. Jednak za formalny początek udokumentowanych dziejów gromadzenia zbiorów przyrodniczych w Uniwersytetu Jagiellońskiego należy uznać rok 1782 . Wtedy bowiem został powołany do życia Gabinet Historii Naturalnej, który dał początek późniejszym uniwersyteckim kolekcjom: geologicznym, botanicznym, zoologicznym i antropologicznym, przechowywanym obecnie w Zielniku, Ogrodzie Botanicznym i Centrum Edukacji Przyrodniczej UJ. Siedzibą Gabinetu Historii Naturalnej była kamienica przy ulicy św. Anny 6 w Krakowie; obecnie znajduje się tam Collegium Kołłątaja (Collegium Physicum) UJ. Ogród Botaniczny (najstarszy w Polsce!) powstał o rok później (1783 r.) i, podobnie jak Gabinet, miał być również zakładem pomocniczym Katedry Chemii i Historii Naturalnej oraz miejscem prowadzenia warsztatów naukowych i prac badawczych.

Założycielem i pierwszym opiekunem Gabinetu Historii Naturalnej oraz pierwszym dyrektorem Ogrodu Botanicznego (17831787) był Jan Dominik Piotr Jaśkiewicz, który był także pierwszym profesorem historii naturalnej Akademii Krakowskiej, powołanym na katedre w 1782 r. (BEIERSDORF i SMAgOWICZ 1984, JuRA 1999). Ten polski chemik, geolog i mineralog pochodzenia or- miańskiego, a także doktor medycyny Uniwersytetu Wiedeńskiego, był od 1783 r. również lekarzem nadwornym Stanisława Augusta Poniatowskiego, króla Polski (lata 17641795) i ostatniego władcy Rzeczypospolitej Obojga Narodów. Jego zainteresowania dotyczyły głównie chemii, geologii i górnictwa (JURA 1999). Uważa się go za twórcę polskiego słownictwa naukowego w mineralogii. Jaśkiewicz wyposażył Gabinet Historii Naturalnej także w kolekcje botaniczne i zoologiczne pochodzace $z$ własnych podróży oraz zakupów dokonanych w Paryżu. Zgromadził tam niewielki zbiór dendrologiczny krajowych gatunków drzew i dwa XVIII-wieczne zielniki przywiezione $z$ południowej Europy, a także bogata kolekcja botaniczna ks. Michała Sołtyka, dziekana kapituły krakowskiej. W zbiorach tych zachowane sa do dziś, m.in. okaz przeciętego orzecha kokosowego i cztery naczynia wykonane $z$ orzecha, $w$ tym puchar rzeźbiony w barokowe ornamenty roślinne, $z$ inicjałem SM i data 1687. Kolekcje ta zapoczątkowała pierwsze publiczne muzeum w Polsce i dały poczatek (obecnemu) Zielnikowi Uniwersytetu Jagiellońskiego (KÖHLER 1991, 1999, 2001a, b). Z inicjatywy prof. Jaśkiewicza w 1782 r. powstało także Muzeum Mineralogiczne, funkcjonujące w obrębie Gabinetu Historii Naturalnej. Gromadzono w nim zbiory minerałów, skał i skamieniałości aż do 1886 r., kiedy to doszło do rozdziału Muzeum Mineralogicznego na dwa oddziały: mineralogiczny i geologiczny. Nowo powstały Gabinet Geologiczny przejął zbiory paleontologiczno-geologiczne i część zbiorów petrograficznych. Potem, do 1805 r. Gabinetem i Ogrodem zarzadzał Franciszek Scheidt, fizyk, chemik i botanik oraz absolwent i profesor Akademii Krakowskiej. Wówczas kolekcja roślin bardzo się rozwinęła. Urządził on i rozbudował Ogród Botaniczny, sprowadzajac okazy z Wiednia, Paryża i Petersburga. Warto dodać, że Scheidt jako pierwszy w Polsce wyhodował w krakowskich cieplarniach banany. Pod koniec XVIII w. zbiory te liczyły już ok. 3000 okazów. Do ponownego scalenia zbiorów doszło w latach 70. XX w., kiedy w nowej siedzibie Instytutu Nauk Geologicznych UJ przy ul. Oleandry 2a powstało Muzeum Geologiczne ING UJ.

Po III rozbiorze Polski władze austriackie mianowały na kierownika Gabinetu Historii Naturalnej kolejno Emmanuela Hirschbauma i Baltazara Hacqueta (BEIERSDORF i SMAGOWICZ 1984). Po przyłączeniu Krakowa do Księstwa Warszawskiego profesorowie ci wyjechali, a Katedrę Historii Naturalnej obją w 1809 r. Alojzy Rafał Estreicher. O pierwszym niewiele wiadomo, natomiast dwaj nasteppni opiekunowie Gabinetu Historii Naturalnej intensywnie powiększali kolekcje przy- 
rodnicze. Baltazar Hacquet był austriackim naturalista pochodzenia francuskiego, który od 1805 do 1809 r. pracował jako profesor chemii i botaniki w Akademii Krakowskiej. W tym okresie krótko pełnił także funkcję zastępcy dyrektora Ogrodu Botanicznego. Był on również profesorem anatomii, etnologiem oraz prekursorem alpinizmu i pionierem badań przyrody Karpat. Hacquet odegrał znaczaca rolę $\mathrm{w}$ dziedzinie badań botanicznych obszarów alpejskich i karpackich, m.in., opisując jako pierwszy tojad mołdawski, Aconitum moldavicum (Hacquet, 1790) i szczodrzeńca zmiennego, Chamaecytisus albus (Hacq.) Rothm., 1944 (RADWAN̂SKA-PARYSKA i PARYSKI 1995). Jego nazwisko zostało upamiętnione $\mathrm{w}$ naukowej nazwie rodzajowej cieszynianki (Hacquetia) oraz w nazwie gatunkowej gnidosza Hacqueta, $\mathrm{Pe}$ dicularis hacquetii Graf, 1834 (RADWAŃSKA-PARYSKA i PARYSKI 1995). Na jego cześć nazwano również kopalnego koralowca Aulopora hacqueti (ZAPALSKI 2005). Z kolei Alojzy Rafał Estreicher był polskim botanikiem i entomologiem. Jako adiunkt pracował w Katedrze Weterynarii, a od 1809 r. w Katedrze Botaniki i Zoologii Akademii Krakowskiej. Był także opiekunem Gabinetu Zoologicznego i dyrektorem Ogrodu Botanicznego (lata 1809-1843), a później również profesorem i rektorem tej uczelni oraz prezesem Towarzystwa Naukowego Krakowskiego. Zgromadził bogata kolekcje krajowych chrząszczy, licząca ponad 31 tysięcy okazów oraz znalazł nowy dla nauki gatunek chrzaszcza $z$ rodziny biegaczowatych (Carabidae), którego opisal Fischer von Waldheim w 1820 r. i nadał mu nazwe Carabus estreicheri. Zawirowania historyczne i zwiazane $z$ nimi dzieje najstarszej w Polsce uczelni doprowadziły w 1811 r. do praktycznej eliminacji Gabinetu Historii Naturalnej, gdyż wówczas Estreicher wydzielił zbiory zoologiczne i botaniczne od pozostałych i utworzył Gabinet Zoologiczny, zalążek późniejszego Muzeum Zoologicznego w Instytucie Zoologii oraz Gabinet Geologii i Mineralogii, przekształcony później w Muzeum Geologiczne. Wyodrębnione kolekcje zoologiczne uzupełnił zbiorami zakupionymi przez Akademię od Baltazara Hacqueta i różnymi darami, przede wszystkim wspomnianego wcześniej biskupa krakowskiego Kajetana Soltyka. Raport profesora Estreichera $z 1838$ r. wskazuje, że Gabinet Zoologiczny posiadał wówczas „5 304 numerów i płodów naturalnych", a pod koniec jego kadencji na katedrze, zbiory liczyły już ok. 8000 numerów. Mieściły się one w dwóch salach $\mathrm{w}$ pierwotnej siedzibie przy ul. św. Anny 6 do drugiej polowy XX w. (BEIERSDORF i SMAGOWICZ 1984, BEIERSDORF 1992, JURA 1999). Natomiast kolekcje botaniczne przeniesiono najpierw do Obserwatorium, a następnie do wschodniego pawilonu Ogrodu Botanicznego, gdzie póżniej część cennych zielników uległa zniszczeniu. Estreicher położył wielkie zasługi dla rozwoju Ogrodu Botanicznego Uniwersytetu Jagiellońskiego (nazwa ta oficjalnie została przyjęta w $1817 \mathrm{r}$.). Oprócz wzbogacenia zbiorów zielnikowych, doprowadził także do powiększenia jego terenu oraz budowy nowego pawilonu i szklarni. Po jego przejściu na emeryturę w 1843 r., przez następne cztery lata, do 1847 r., kierownikiem Gabinetu Zoologicznego i dyrektorem Ogrodu Botanicznego był Ignacy Rafał Napoleon Czerwiakowski, profesor historii naturalnej (od 1843 roku) i profesor botaniki (1850-1870), polski botanik i lekarz, pierwszy kierownik Katedry Botaniki utworzonej w 1848 r. oraz późniejszy rektor UJ (1862-1863). Dzięki niemu, poprzez zakupy i wymiany, zbiory zoologiczne wzbogaciły się o kolejne 655 pozycji. Powiększyły się też zbiory zielnikowe, a Ogród Botaniczny, którego inspektorem w tym czasie został Józef Warszewicz (jeden $z$ bardziej znanych $\mathrm{w}$ ówczesnej Europie badaczy i kolekcjonerów roślin środkowej i południowej Ameryki), stał się jednym $z$ czołowych ogrodów środkowej Europy. Należy także podkreślić, że profesor Czerwiakowski jest autorem pierwszego uniwersyteckiego podręcznika botaniki w Polsce „Botanika ogólna roślin jawnopłciowych" (t. 1-2, 1841) i „Botaniki szczególnej” (t. 1-6, 1849-63) oraz „Botaniki lekarskiej...” (1861).

Po właczeniu Wolnego Miasta Krakowa do Galicji, w wyniku reformy studiów w 1847 r. władze austriackie powierzyły opieke nad Gabinetem Zoologicznym profesorom Hermanowi Maksymilianowi Schmidtowi (1847-1848), a po nim, do 1855 r. Ludwikowi Zejsznerowi, którzy wzbogacili zbiory o dalsze 430 pozycji. Choć kolejny niemiecki profesor Eduard Oskar Schmidt pracował w Krakowie tylko dwa lata (1855-1857), to pozostały po nim znaczace kolekcje gabek i gadów. Po 1857 r. Gabinetem kierowali: dr Bernard Brühl (1858) i prof. Kamil Heller (1858-1861), a potem kuratorem Gabinetu Zoologicznego został ponownie Czerwiakowski (1861-1863), profesor botaniki. W 1855 r. po raz pierwszy Gabinet nazwano urzędowo Muzeum Zoologicznym i odtąd obie nazwy funkcjonowały zamiennie, choć ostatecznie przyjęła się ta druga.

W 1863 r. kierownikiem Muzeum i powstałej w 1850 r. Katedry Zoologii z Anatomia Porównawcza (mieściła się w Collegium Physicum przy ul. Św. Anny 6) został prof. Maksymilian Siła Nowicki, pierwszy polski zoolog (entomolog, ichtiolog) w UJ (JURA 1992). Wówczas rozpoczał się prawdziwy rozwój zoologii i widoczny wzrost liczby 
gromadzonych kolekcji zoologicznych. Nowicki po swoich poprzednikach zastał ok. 12200 okazów reprezentujących ok. 4500 gatunków, a pod koniec jego działalności w 1887 r., kolekcje muzealne liczyły już 36000 eksponatów należących do 15500 taksonów. Ten wybitny przyrodnik, oprócz tego, że miał największe zasługi w opiece i wzbogacaniu zbiorów zoologicznych w XIX w., był także badaczem fauny i flory tatrzańskiej, pionierem ochrony przyrody w Polsce oraz współtwórca Towarzystwa Tatrzańskiego. Stworzył krakowska szkołę zoologiczna z ukierunkowana faunistyka, która szybko uzyskała międzynarodowe uznanie. Już w 1852 r., jako zastępca nauczyciela Gimnazjum w Samborze zaczął gromadzić zbiory entomologiczne, którymi obdarowywał gimnazja. Wtedy też rozpoczął wieloletnia współprace $z$ Włodzimierzem Dzieduszyckim, w efekcie czego przyczynił się znacznie do rozwoju niektórych kolekcji Muzeum Przyrodniczego im. Dzieduszyckich we Lwowie. Do ok. 1875 r. aktywnie badał chrzasszcze i motyle Galicji oraz faunę tatrzańską, po czym zajął się głównie ichtiologia i rybołówstwem. Na podstawie obserwacji terenowych i laboratoryjnych oraz licznie nagromadzonych zbiorów opublikował wiele podręczników dydaktycznych, a także masę cennych, aktualnie cytowanych publikacji naukowych. Po smierci Maksymiliana Nowickiego Katedrę Zoologii oraz kierownictwo Zakładu i Muzeum Zoologicznego objął w 1891 r. jego uczeń prof. Antoni Wierzejski, polski zoolog i hydrobiolog. Kierował nimi do 1912 r., uzupełniajacc zbiory głównie bezkręgowcami, w szczególności wodnymi. Od 1912 r. do wybuchu II wojny światowej Muzeum opiekował się prof. Michał Siedlecki, który w pracy badawczej zajmował się protozoologia, cytologia i biologia morza. Po zajęciu Krakowa przez hitlerowców, III Rzesza przeprowadziła 6 listopada 1939 r. tzw. "Sonderaktion Krakau”. Wśród aresztowanych profesorów i innych pracowników szkół wyższych znaleźli się profesorowie Siedlecki i Roman Wojtusiak (etolog i lepidopterolog). Wówczas dokonany został także akt wandalizmu wobec okazów i preparatów oraz aparatury w Muzeum Zoologicznym, które miało przestać istnieć (BEIERSDORF 1992). Pomimo tego udało się uratować wiele $z$ nich dzięki kilku pracownikom narażajacym swe życie. Czasy II wojny światowej zbiory zoologiczne, częściowo ukryte przez nich, przetrwały na strychu Collegium Physicum, a od 1943 r. były ponownie wykorzystywane w tajnym nauczaniu studentów biologii. Działaniami tych pracowników kierował poczatkowo prof. Władysław Szafer (botanik), a po powrocie $z$ obozu koncentracyjnego prof. Zygmunt Grodziński (zoolog, anatom i embriolog). W tajnym nauczaniu zoologię ogólną i systematyczną wykładał ówczesny doc. Wojtusiak, a zoogeografię i etologię doc. Józef Fudakowski (entomolog i zoogeograf). W edukacji tej uczestniczył także Wiktor Micherdziński (zoolog), który zajmował się systematyka oraz porząlkowaniem i zabezpieczaniem części uniwersyteckich kolekcji zoologicznych, a po latach (w 1966 r.) został kierownikiem Muzeum.

Po odzyskaniu niepodległości w 1945 r. kierownictwo Katedry Zoologii Systematycznej i opiekę nad zbiorami objął prof. Stanisław Smreczyński, morfolog i systematyk owadów, jeden $z$ najlepszych $w$ skali światowej znawców fauny ryjkowców (Curculionoidea). Sam też zgromadził bogata kolekcję tych chrzaszzczy, która po jego śmierci została sprzedana przez jego żonę i obecnie znajduje się w Instytucie Systematyki i Ewolucji Zwierząt PAN w Krakowie. Wówczas samymi zbiorami zoologicznymi zajmowali się późniejsi profesorowie Zbigniew Kawecki i Józef Mikulski oraz wspomniany wcześniej doc. Wiktor Micherdziński. Były one wtedy mało dostępne dla zwiedzajacych i korzystali $z$ nich głównie pracownicy i studenci Wydziału Biologii i Nauk o Ziemi. Po zmianie struktury Wydziału w 1967 r. zbiory zoologiczne $z$ ul. św. Anny 6 zostały pod kierunkiem doc. Micherdzińskiego przeniesione do nowej siedziby, nowo utworzonego i odrębnego Muzeum Zoologicznego, jako jednego $z$ zakładów Instytutu Zoologii UJ, przy ul. Ingardena 6. Od 1980 r. Muzeum kierował docent, a potem prof. Janusz Wojtusiak, wybitny lepidopterolog. Ówczesne Muzeum gromadziło ok. 7000 okazów reprezentujących prawie wszystkie typy królestwa Animalia, prezentowanych w głównej ekspozycji zoologicznej oraz ok. 1500 gatunków muszli mięczaków (Mollusca), 500 gatunków skamieniałości i 1200 gatunków motyli (Lepidoptera), two-

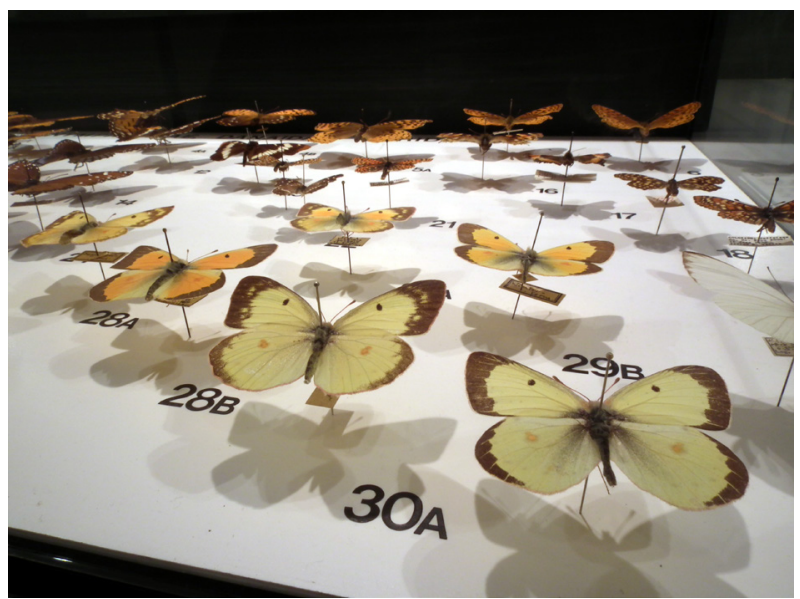

Ryc. 1. Dawna wystawa motyli przy ul. Grodzkiej 53 (fot. A. Czekaj). 


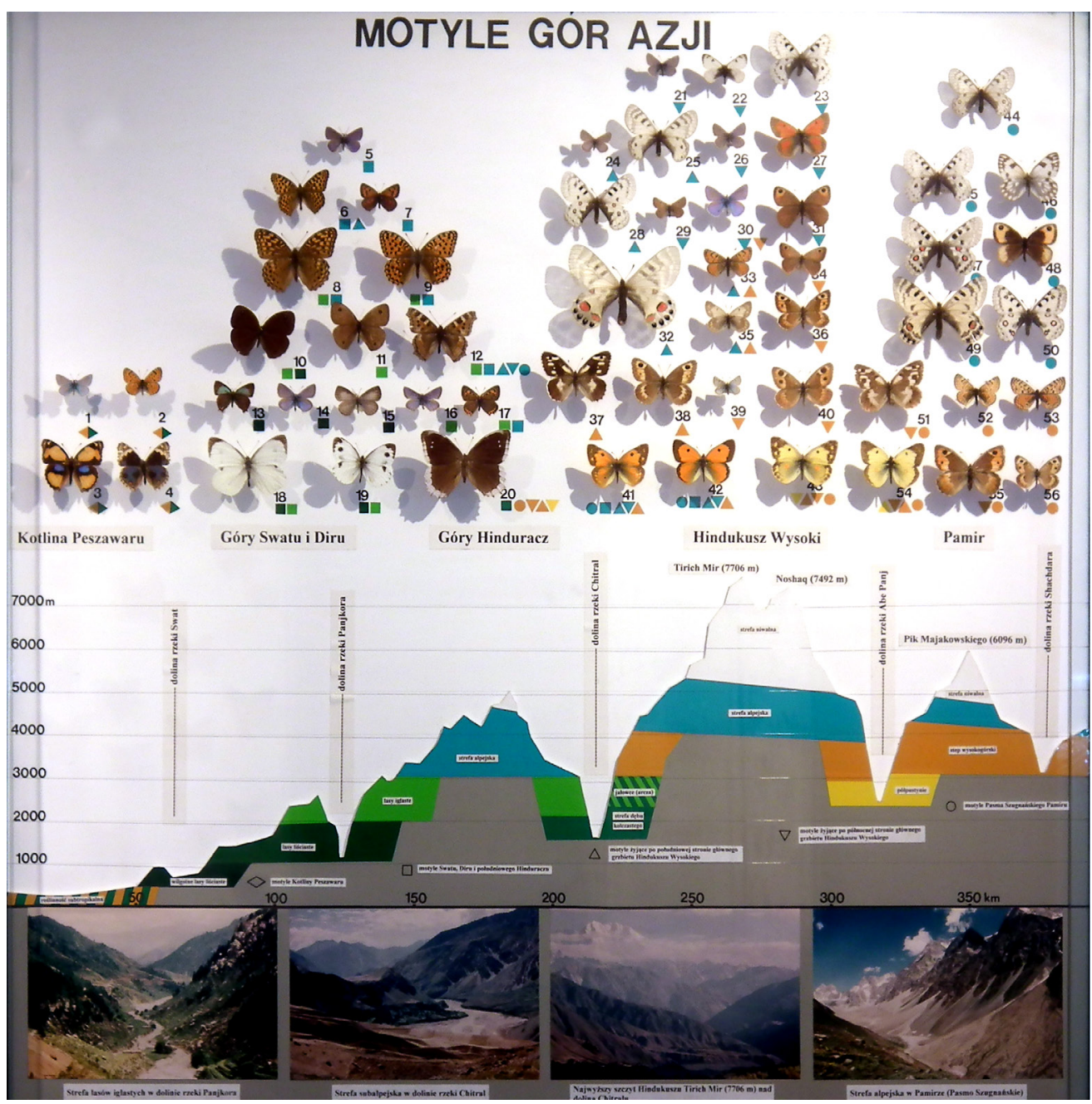

Ryc. 2. Dawna wystawa motyli przy ul. Grodzkiej 53, gablota „Motyle gór Azji” (fot. A. Czekaj).

rzących wystawę w podziemiach Collegium Iuridicum UJ przy ul. Grodzkiej 53 (Ryc. 1, 2). Ze względu na głównie dydaktyczny charakter Muzeum, a także jego szczuple zaplecze magazynowo-techniczne, wiele okazów, zwłaszcza większych, o znaczeniu naukowym, było wystawianych w ekspozycji ogólnej, natomiast ponad 20000 egzemplarzy było zdeponowanych w magazynach. W ostatnim okresie swego istnienia Muzeum Zoologiczne nadal gromadziło i udostępniało zbiory fauny Polski, a w zakresie motyli i mięczaków także $z$ różnych części świata. Do najcenniejszych jego osobliwości przyrodniczych należały: czaszka wymarłej krowy morskiej lub syreny morskiej Hydrodamalis gigas (Zimmermann, 1780) [= Rhytina stelleri Brandt, 1849] (Ryc. 3), szkielet nosorożca włochatego, Coelodonta antiquitatis (Bronn, 1831) (Ryc. 4), dwa gatunki łuskowców: Manis javanica (Desmarest, 1822) i $M$. macroura Erxleben, 1777 oraz zmontowany szkielet płetwala karłowatego, Balaenoptera acutorostrata Lacépède, 1804 (Ryc. 5). Pod względem systematycznym stan kolekcji zoologicznych Muzeum na poczatku lat 90. XX w. przedstawiał się następująco (BEIERSDORF i SMAGOWICZ 1984):

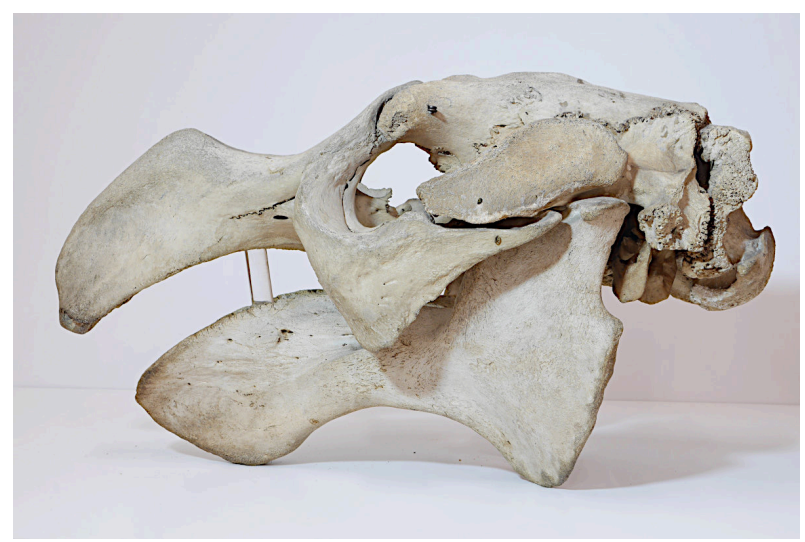

Ryc. 3. Czaszka krowy morskiej, † Hydrodamalis gigas, (Zimmermann, 1780), pozyskana przez B. Dybowskiego w czasie wyprawy na Daleki Wschód w 1880 r. - jedyny eksponat tego gatunku w polskich muzeach (fot. A. Czekaj). 


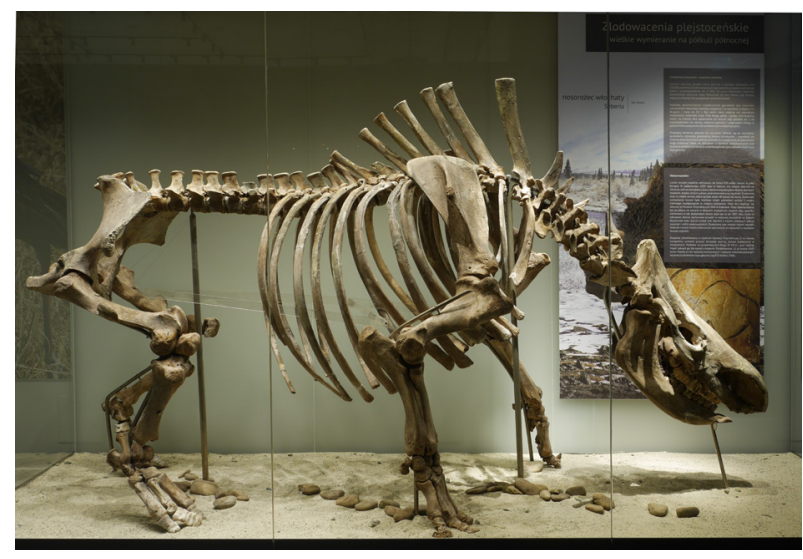

Ryc. 4. Szkielet samicy nosorożca włochatego, $\dagger$ Coelodonta antiquitatis (Bronn, 1831), znaleziony w miejscowości Podbaba w okolicach Pragi, zakupiony w 1914 r. przez Hoyera za 4500 koron dla Zakładu Anatomii Porównawczej (fot. A. Czekaj).

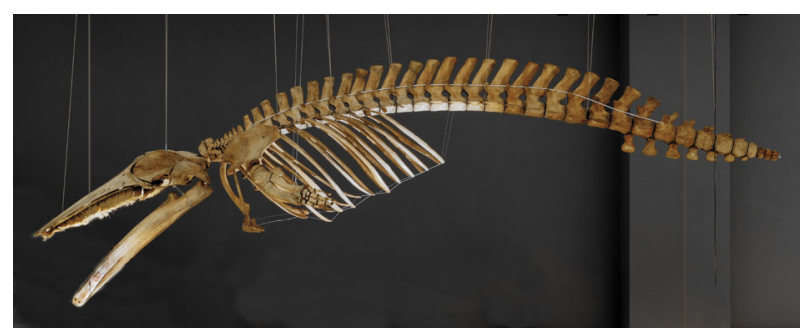

Ryc. 5. Szkielet płetwala karłowatego, Balaenoptera acutorostrata Lacépède, 1804, zakupiony w częściach w 1903 r. w Hamburgu (Niemcy), złożony w latach 60. XX w. dla celów ekspozycji (fot. A. Czekaj).

- gabki (Spongiaria, Porifera), reprezentowane przez 25 gat. $z$ Adriatyku, które zostały przekazane przez O. Schmidta;

- skorupiaki (Crustacea), zbiór obejmuje 2 słoje $z$ kiełżami bajkalskimi Pallasea cancellus (Pallas, 1772) [dawniej Gammarus cancellus (Pallas, 1772)], przekazanymi przez Benedykta Dybowskiego (Ryc. 6), kolekcje krabów cejlońskich (jeszcze nie oznaczonych) oraz zbiory zooplanktonu $z$ południowej Polski, obejmujące: wioślarki (Cladocera), widłonogi (Copepoda) i małżoraczki (Ostracoda); Micherdziński swoje zbiory i preparaty kiełży, Gammarus sp. i studniczków, Niphargus sp. przekazał do Uniwersytetu Łódzkiego;

- pajęczaki (Arachnida), szczególnie roztocze (Acarina) liczace ok. 6000 okazów na preparatach mikroskopowych opracował Micherdziński, a kilkadziesiąt prób z kleszczami (Ixodida) zakonserwowanych jest w alkoholu;

- owady (Insecta), najliczniejsza i najbardziej różnorodna grupa, były gromadzone przez różnych autorów, w tym zbiory: muchówek (Diptera) M.S. Nowickiego - obejmo-

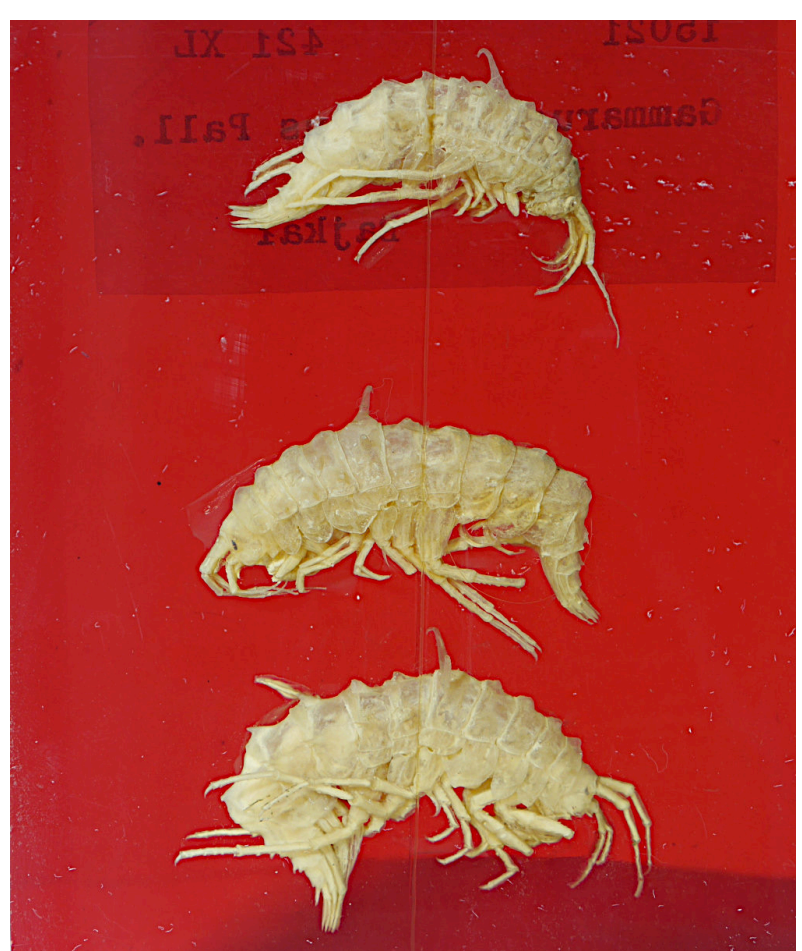

Ryc. 6. Kiełże, Pallasea cancellus (Pallas, 1772) z Bajkału, przekazane przez B. Dybowskiego (fot. A. Czekaj).

wał ponad 30 pudeł $z$ opisana zawartościa wraz $z$ jego notatkami; motyli (Lepidoptera) - uporzadkowane i wystawione materiały dowodowe pracy T. Garbowskiego dotyczace przepoczwarczania się widłogonek (Dicranura); inne grupy motyli pochodzace $z$ różnych rejonów świata na podstawie etykiet zbiorów, były scalone i w części wystawione; istniała też kontynuowana kolekcja motyli R. Wojtusiaka, uzupełniana przez J. Wojtusiaka, pochodząca $z$ Europy, Azji i Afryki, a także motyle $z$ Nigerii przekazane przez R. Tertila oraz błonkówki (Hymenoptera) - nieuporządkowana kolekcja E. Lubicz-Niezabitowskiej;

- mięczaki (Mollusca), reprezentowane przez ponad 3000 gat. egzotycznych i historyczna kolekcję (gablota $z$ zestawionymi przez M.S. Nowickiego okazami) obejmujaca wszystkie znane wówczas gatunki ówczesnej Galicji;

- ryby (Pisces), kilkadziesiąt pojemników z rybami galicyjskimi ofiarowanymi przez $\mathrm{M}$. S. Nowickiego i zestaw larw wegorza przekazany przez J. Schmidta $z$ jego pierwszej wyprawy na Morze Sargassowe;

- płazy (Amphibia), kilka gatunków żab, przywiezionych w 1853 r. przez Józefa Warszewicza $z$ Ameryki Południowej i majacych dużą wartość naukowa (trzy $z$ nich to lektotypy przechowywane w płynie konserwujacym), zostało opisanych przez profesora $\mathrm{O}$. Schmidta; 


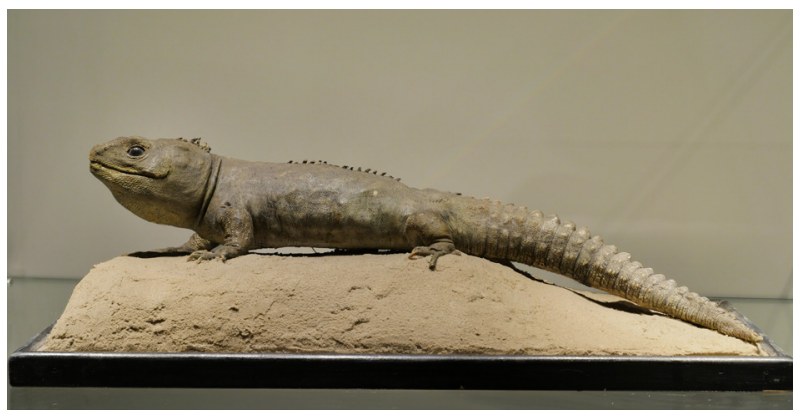

Ryc. 7. Hatteria, Sphenodon punctatus (Gray, 1842), ofiarowana przez K. Wodzickiego (fot. A. Czekaj).

- gady (Reptilia), najciekawszym $z$ nich jest hatteria (inaczej tuatara lub łupkozą), Sphenodon punctatus (Gray, 1842), ofiarowany przez K. Wodzickiego (Ryc. 7);

- ptaki (Aves), do osobliwości zoologicznych należy kolekcja ptaków $z$ krainy australijskiej: kiwi, Apteryx sp. i kakapo, Strigops habroptila G.R. Gray, 1845 (Ryc. 8) oraz 9 rajskich ptaków (cudowronki, cudowronkowate) z Nowej Gwinei;

- ssaki (Mammalia), oprócz wymienionych wcześniej osobliwości wystawy, wiele gatunków wypchanych ssaków Polski.

Muzeum Zoologiczne Instytutu Zoologii w takiej formie ze swoim inwentarzem funkcjonowało przy ul. Ingardena 6 do 2017 r., kiedy jego kolekcje zostały włączone do zbiorów Centrum Edukacji Przyrodniczej (CEP) przy ul. Gronostajowej 5 na Kampusie UJ. Podobnie jak zbiory zoologiczne, zbiory botaniczne systematycznie wzbogacano w XIX i $\mathrm{XX}$ w. oraz na poczatku obecnego stulecia. W drugiej połowie XIX w., od kolekcji ogro-

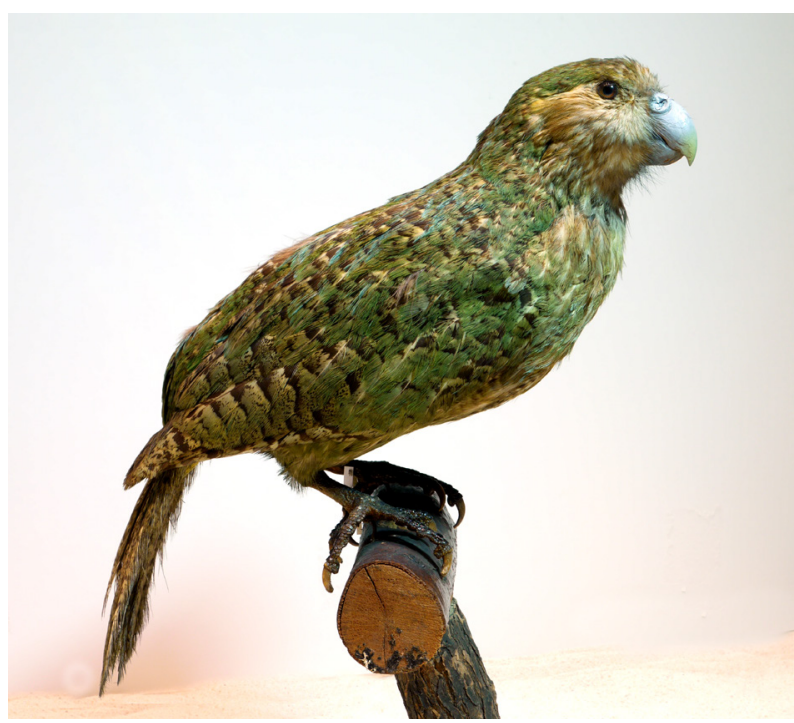

Ryc. 8. Papuga kakapo, Strigops habroptila G. R. Gray, 1845, z XIX w., pochodzenie nieznane (fot. A. Czekaj).

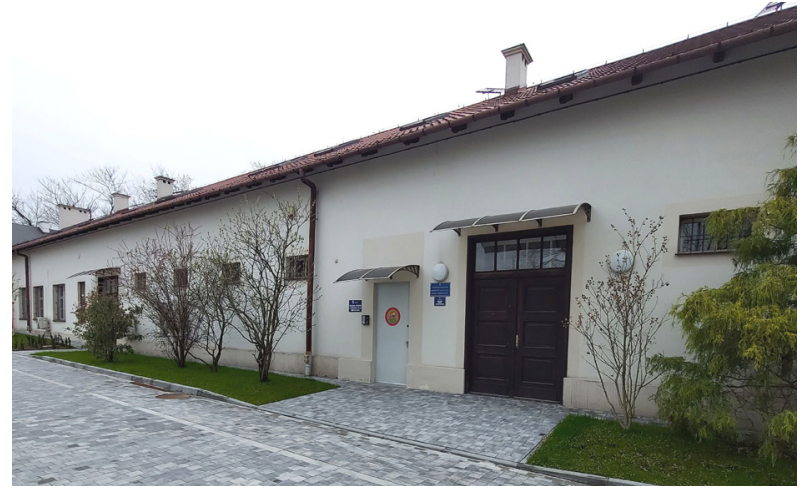

Ryc. 9. Budynek Zielnika Uniwersytetu Jagiellońskiego przy ul. Kopernika 31 (fot. M. Nobis).

du oddzielony został zbiór zielnika, liczący wówczas kilkadziesiąt tysięcy arkuszy, a w dużej sali na parterze Obserwatorium zorganizowano wystawę wybranych okazów muzealnych, która przetrwała do pierwszej wojny swiatowej.

W 1910 r. Rada Wydziału Filozoficznego Uniwersytetu Jagiellońskiego zaproponowała Marianowi Raciborskiemu (botanikowi i profesorowi UJ, badaczowi roślin i grzybów dawnych ziem polskich oraz Indonezji, odkrywcy wielu nowych gatunków, autorowi pionierskich prac $z$ paleobotaniki i pionierowi ruchu ochrony przyrody w Polsce) kierownictwo Katedry Botaniki i dyrekcję Ogrodu Botanicznego. Funkcje te objął jednak dopiero w 1912 r. po przybyciu do Krakowa ze Lwowa. Raciborski przywiózł wówczas ze soba bogate zbiory zielnikowe i dużą prywatna bibliotekę. Umieścił je w zachodnim pawilonie Ogrodu i rozpoczą prace nad uporzadkowaniem oraz konserwacja zbiorów. Rok później (1913) utworzył Instytut Botaniczny, który miał swoja siedzibę w kamienicy przy ul. Lubicz 46. Instytucja ta pod nazwa Instytut Botaniki UJ funkcjonuje do dziś, choć aktualnie jest ulokowany przy ul. Kopernika 27 i 31 oraz przy ul. Gronostajowej 3 w Krakowie (Ryc. 9). Po śmierci Raciborskiego, jego siostrzeniec i spadkobierca Adam Stobiecki przekazał do Zielnika UJ w 1920 r. jedna z najcenniejszych kolekcji Profesora - bogate zbiory botaniczne jawajskich zielników obejmujace tropikalne gatunki, które zebrał w Indonezji, głównie na Jawie w latach 1897-1900, w tym wiele okazów typowych (holotypów, izotypów i syntypów gatunków roślin i grzybów opisanych przez Raciborskiego) (Ryc. 10). Dzięki temu powiększyły się znacznie zbiory Muzeum Ogrodu Botanicznego. Zasadniczą część tej kolekcji (ok. 1500 okazów) stanowiły zielniki, zbiory dendrologiczne, karpologiczne oraz okazy mokre zakonserwowane w płynach i 


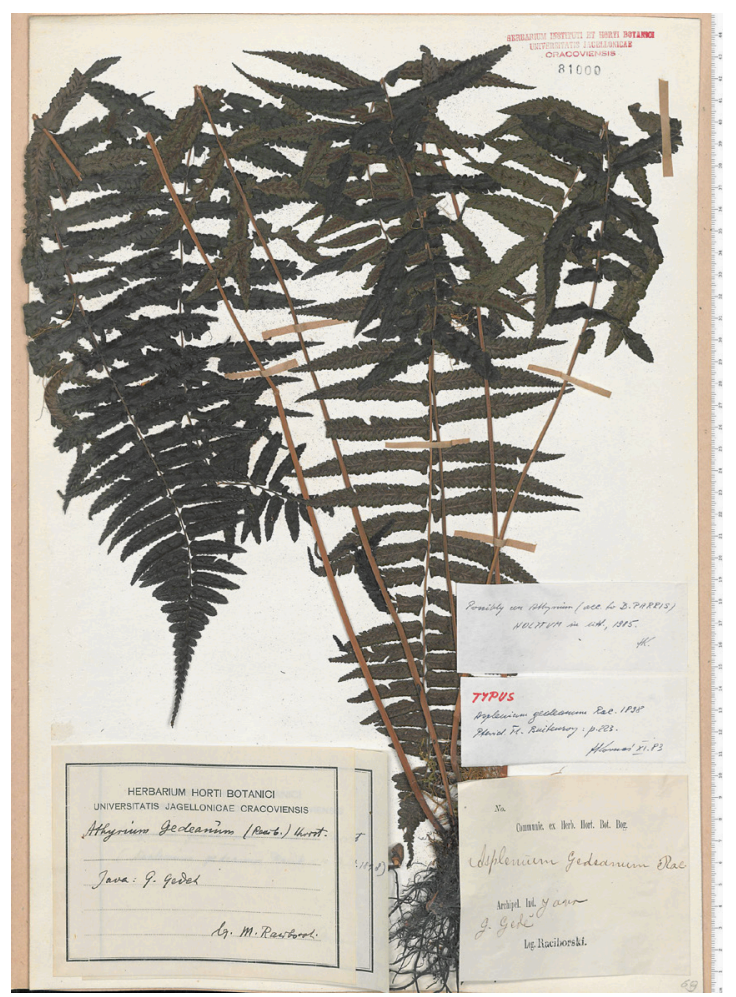

Ryc. 10. Asplenium grandeanum Racib. z Jawy, holotyp gatunku (KRA 81000) (fot. M. Nobis).

przechowywane w słojach oraz próbówkach $i$ in., a także liczne okazy nasion, owoców, drewien, jak również wyroby $z$ materiałów roślinnych. Część krajowych zbiorów Raciborskiego zakupił Włodzimierz Dzieduszycki (1885-1971) dla Muzeum Przyrodniczego im. Dzieduszyckich we Lwowie. Natomiast egzotyczne kolekcje etnograficzne zgromadzone przez Raciborskiego na Jawie, liczace 206 obiektów, wśród których znajduja się lalki teatralne $z$ tradycyjnych teatrów jawajskich wayang golek purwa i wayang golek menak, broń, tkaniny i wyroby rzemiosła, znajduja się obecnie w Muzeum Etnograficznym im. Seweryna Udzieli w Krakowie (KÖHLER i ZEMANEK 2018). Z prof. Raciborskim zwiąane sa także poczatki powstawania kolekcji skamieniałości roślinnych w Instytucie Botaniki. Po śmierci Raciborskiego, jego następca w kierowaniu Instytutem i Ogrodem Botanicznym (w latach 1917-1941 i 1945-1960) oraz kontynuatorem wielu jego idei został prof. Władysław Szafer, jeden $z$ najsławniejszych polskich przyrodników i botaników. Dążył do stworzenia naukowych podstaw ochrony przyrody, a jednym $z$ pierwszych na świecie podręczników w tym zakresie było zainicjowane przez niego, 2-tomowe dzieło zbiorowe "Ochrona przyrody $i$ jej zasobów”. Zajmował się także florystyka, paleobotanika i geografią roślin. Był on również rektorem UJ w latach 1936-1938. Za jego czasów doszło
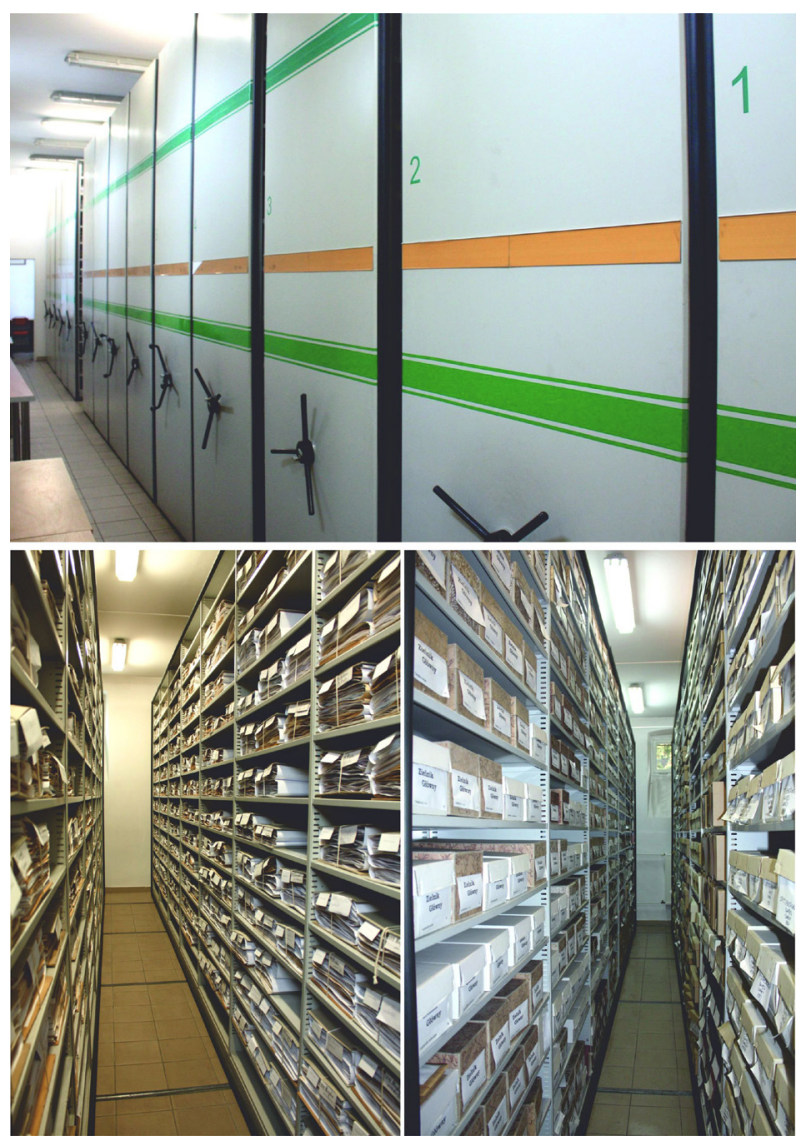

Ryc. 11. Kolekcje roślin naczyniowych (lewy dół) i porostów (prawy dół) przechowywane w szafach kompaktowych w Zielniku UJ (fot. M. Nobis).

do podziału kolekcji zielnika i przekazania części okazów znanej szeroko jako „Zielnik KRAM" do Kolekcji Instytutu Botaniki im. W. Szafera Polskiej Akademii Umiejętności (KÖHLER 2001b).

W czasie II wojny światowej zbiory były wielokrotnie przenoszone i część uległa zniszczeniu. Jednak większość przetrwała dzięki staraniom polskiego personelu zatrudnionego w Ogrodzie. $Z$ powodu trudności lokalowych nie było jednak stałego pomieszczenia magazynowego ani większej ekspozycji. Dzięki staraniom prof. Kazimierza Szczepanka, dyrektora (1973-1991) Ogrodu Botanicznego, w 1978 r. zbiory umieszczono w 7 pomieszczeniach XVII-wiecznych wnętrz na parterze dawnego Obserwatorium Astronomicznego (obecnie Collegium Śniadeckiego UJ), znajdującego się jednak w bardzo złym stanie technicznym. W czasie uroczystości jubileuszu 200-lecia istnienia Ogrodu Botanicznego UJ 26 maja 1983 r. otwarto stała ekspozycję. Wystawa muzealna obejmowała 4 sale ekspozycyjne na parterze Collegium Śniadeckiego, z wejściem od strony ogrodu. W 1994 r. Muzeum w Ogrodzie Botanicznym zyskało status pracowni o nazwie: Muzeum 
Botaniczne i Pracownia Historii Botaniki im. J. Dyakowskiej. Do lat 90. ubiegłego wieku nad rozwojem kolekcji zielnika czuwał prof. Jan Kornaś, wieloletni dyrektor Instytutu Botaniki, wybitny florysta, fitogeograf, fitosocjolog, który w czasie wielu swoich wypraw zebrał olbrzymie zbiory roślin naczyniowych $z$ wielu rejonów świata, w tym $z$ Polski, wielu rejonów Europy, Ameryki Północnej, południowo-wschodniej Azji oraz przede wszystkim $z$ Afryki, gdzie prowadził swoje wieloletnie badania naukowe. Natomiast na przełomie XX i XXI w., $z$ inicjatywy ówczesnego dyrektora Instytutu Botaniki, prof. Adama Zajacca, wybitnego fitogeografa, florysty i taksonoma, współautora m.in. „Atlasu rozmieszczenia roślin naczyniowych $w$ Polsce", wszystkie kolekcje roślin naczyniowych, mchów, wątrobowców, grzybów i śluzowców, przeniesiono do osobnego budynku - Zielnika (Herbarium) Instytutu Botaniki UJ, urzadzonego w 2001 r. w kompleksie zabudowań przy ul. Kopernika 31 (Ryc. 9), gdzie znajdują się do dziś. Natomiast w 2016 r. przy okazji przeprowadzki Instytutu Botaniki $z$ ul. Kopernika 27 i ul. Lubicz 46 na Kampus UJ przy ul. Gronostajowej 3, do Zielnika przeniesiono wszystkie pozostałe zbiory roślin naczyniowych oraz cała kolekcję zbiorów grzybów lichenizujących (porostów) (Ryc. 11). Na przełomie XX i XXI w. Herbarium odnotowało największe przyrosty kolekcji okazów zielnikowych w obrębie wszystkich grup systematycznych. Prowadzono wówczas bardzo intensywne badania dotyczące rozmieszczeni wielu taksonów roślin, grzybów i porostów w Polsce oraz w innych obszarach świata, a kolekcja wzbogacała sie o kilkanaście, kilkadziesiąt tysięcy okazów rocznie. W 2021 r. Zielnik Instytutu Botaniki został przeniesiony ze struktury Zakładu Taksonomii, Fitogeografii i Paleobotaniki Instytutu Botaniki w struktury Ogrodu Botanicznego, w obrębie którego znajdował się od początku swojego istnienia.

\section{OBECNE ZASOBY KOLEKCJI PRZYRODNICZYCH UJ}

Obecne zbiory przyrodnicze Uniwersytetu Jagiellońskiego obejmuja kolekcje geologiczne, antropologiczne, paleobotaniczne, botaniczne i zoologiczne. Zbiory botaniczne, w tym zielnik, zgromadzone sa w Herbarium Universitatis Iagellonicae Cracoviensis (KRA) Instytutu Botaniki UJ przy ul. Kopernika 31. Większość pozostałych kolekcji, w tym motyle (Lepidoptera), znajduje się w Centrum Edukacji Przyrodniczej Uniwersytetu Jagiellońskiego (CEP) przy ul. Gronostajowej 5, które jest jednostka pozawydziałowa, gromadzaca zbiory przyrodnicze przechowy- wane $\mathrm{i}$ bedace uprzednio pod opieka muzeów wydziałowych: Muzeum Geologicznego, Muzeum Antropologiczne przy ówczesnym Zakładzie Antropologii, Muzeum Paleobotanicznego i Muzeum Zoologicznego. Centrum Edukacji Przyrodniczej UJ kontynuuje ich historię i tradycję. Oprócz wymienionych sa jeszcze indywidualne kolekcje jettek (Ephemeroptera) i widelnic (Plecoptera) w Instytucie Nauk o Środowisku UJ (ul. Gronostajowa 7), chrzaszczy (Coleoptera) $z$ nadrodziny ryjkowców (Curculionoidea) i niesporczaków (Tardigrada) w Instytucie Zoologii i Badań Biomedycznych UJ (ul. Gronostajowa 9).

\section{KOLEKCJE PALEOBOTANICZNE}

Od czasów prof. Mariana Raciborskiego w Instytucie Botaniki były i nadal sa prowadzone badania skamieniałości roślinnych z różnych okresów geologicznych, począwszy od dewonu po czwartorzęd. Równolegle $z$ nimi, prowadzone były również badania $z$ zakresu palinologii, a ich efektem było powstanie kolekcji materiałów czwartorzędowych w postaci spreparowanej i próbek badanych osadów. Zbiór skamieniałości roślinnych i skał fitogenicznych mieścił się dawniej w Muzeum Paleobotanicznym, a wystawiana niegdyś w Ogrodzie Botanicznym ekspozycja przedstawiała ewolucję świata roślinnego we wszystkich okresach geologicznych. Kolekcje muzealne, zawierajace między innymi szlify $i$ preparaty mikroskopowe $z$ ery paleozoicznej, mezozoicznej i kenozoicznej, pierwsze naczyniowe rośliny lacdowe, paprotniki okresu karbonu, czy skamieniałe drewna, zostały z Instytutu Botaniki przekazane w 2017 r. do nowo powstałego budynku CEP. Zbiory te obejmuja makro-, mezo- oraz mikroskamieniałości roślinne w większości datowane na karbon, neogen i czwartorzęd oraz dokumentację materiałowa badań współczesnego opadu pyłku. Wybrane okazy, reprezentujace różne grupy systematyczne roślin $z$ poszczególnych okresów geologicznych, wystawiane sa w ramach stałej ekspozycji „Ewolucja Ziemi i życia” w obrębie poszczególnych bloków geologicznych. Do głównych kolekcji zbioru skamieniałości roślinnych i skał fitogenicznych przechowywanych obecnie w CEP UJ należą: makroflora karbońska, materiał ze zwałowisk, skamieniałości przedstawicieli Lycophyta, Sphenophyta, Pterophyta, Lyginopteropsida, Cordaitopsida: Górnośląskie Zagłębie Węglowe (Bieruń, Jaworzno, Kaczyce, Jastrzębie, Knurów, Murcki i inne), Dolnośląskie Zagłębie Węglowe (Nowa Ruda, Wałbrzych), Cuticulae dispersae (szczątki roślinne i oskórki stawonogów) oraz inne mezoskamieniałości (głównie zwęglone drewno) z Górnośląskiego i Lubelskiego Zagłębia Węglowego, materiał wypreparowany $z$ wegla 
kamiennego w postaci suchej oraz preparaty mikroskopowe; megaspory i mikrospory wieku karbońskiego $\mathrm{z}$ obszaru obecnych granic Polski; makroflora liściowa (głównie skamieniałości przedstawicieli Magnoliopsida), ksylity i skały fitogeniczne wieku mioceńskiego (Bełchatów); zmineralizowane drewna $Z$ różnych rejonów, głównie $z$ Polski (okolice Kwaczały, Roztocze, Radłów, Dolny Ślask i inne); materiały palinologiczne $z$ czwartorzędu $z$ Polski (próbki $z$ rdzeni wiertniczych i materiał spreparowany); dokumentacja materiałowa badań współczesnego opadu pyłku, $\mathrm{w}$ tym monitoringu aerobiologicznego prowadzonego w Ogrodzie Botanicznym Instytutu Botaniki UJ. Oprócz wspomnianych wcześniej zbiorów botanicznych w CEP znajdują się również inne kolekcje flory kopalnej, które zostały przeniesione $z$ Muzeum Geologicznego Instytutu Nauk Geologicznych UJ. Znaczna część tych zbiorów wymaga jednak szczegółowej inwentaryzacji i będzie mogła być udostępniana szerzej do badań naukowych dopiero po jej dokonaniu.

\section{KOLEKCJE ANTROPOLOGICZNE}

Historia gromadzenia zbiorów antropologicznych w UJ rozpoczyna się od drugiej połowy XIX w., kiedy zaczęto pozyskiwać kostny materiał ludzki $z$ różnych rejonów świata (Europa, Afryka, Azja, Ameryka Płd.) i zwierzęcy (małpy) z nieżyjacych osobników z różnych ogrodów zoologicznych (GŁĄB i KOSYDARSKI 1984). Muzeum Antropologiczne zostało oficjalnie powołane do życia pod koniec XIX w. przez prof. Izydora Kopernickiego, antropologa i lekarza wojskowego (lata 1847-1859), który również założył muzeum anatomiczne i zootomiczne w Bukareszcie. Prowadził badania kraniologiczne, zarówno na czaszkach ludzi żyjacych, jak również $z$ czasów przedhistorycznych, zwłaszcza ludności Galicji i innych plemion słowiańskich, a także Cyganów, Ajnów i innej ludności. Ponadto zbudował nowy kraniograf i ulepszył metody pomiaru czaszek. Swe bogate zbiory antropologiczne pozostawił Uniwersytetowi Jagiellońskiemu. Opiekę nad Muzeum Antropologicznym funkcjonujacym przy Zakładzie Antropologii sprawowali nastepni po Kopernickim kierownicy Zakładu Antropologii UJ. W takiej formie przetrwało ono do 2016 r., kiedy jego zbiory zaczęto przenosić do budynku CEP, a proces ten zakończył się w 2017 r.

Kolekcje Muzeum Antropologicznego w pierwszej połowie lat 90. XX w. obejmowały 22 szkielety różnych przedstawicieli naczelnych oraz duży zestaw kraniologiczny i postkranialny, począwszy od neolitu, a skończywszy na XVIII w., pochodzący głównie $z$ obszaru Europy. $Z$ Azji muzeum po- siadało najliczniejsze w Polsce serie czaszek Ajnów i Mongołów. Ponadto dysponowało 87 czaszkami małp (Ryc. 12) i eksponowało 12 okazów wypchanych małp. Do najbardziej interesujacych eksponatów należały mumifikacje celowe dwóch ludzkich głów z Egiptu, zdeformowane czaszki $z$ Peru oraz Boliwii, szczatki kostne ze zmianami patologicznymi przebytej kiły lub trądu i okaleczeń mechanicznych (GŁĄB i KOSYDARSKI 1984).

\section{KOLEKCJE BOTANICZNE}

Historię Zielnika Uniwersytetu Jagiellońskiego od czasów jego powstania do lat 2000-nych, wraz $z$ jego dziejami, historia zarządzania, pozyskiwaniem kolekcji, przyrostem liczby okazów, interesujaco i bardzo wnikliwie przedstawił prof. Piotr KöHLER (1999, 2001a, b). Obecnie zbiory botaniczne Zielnika Uniwersytetu Jagiellońskiego (akronim KRA - Index herbariorum 2021) można szacować na około 900000 okazów. Pochodzą ze wszystkich kontynentów świata, w tym $z$ wielu krajów i obszarów Europy, Afryki, Azji, Australii, Ameryki Południowej i Północnej oraz Arktyki i Antarktydy. Z roku na rok przybywa okazów, a roczny wzrost kolekcji szacuje się obecnie na ok. 10000 alegatów. Zbiory botaniczne obejmuja: grzyby i śluzowce: ponad 35000 okazów; porosty: ok. 100 000; mszaki, w tym mchy i wątrobowce: około 15 000; a także rośliny naczyniowe. Ta ostatnia grupa liczy razem ponad 700000 arkuszy zielnikowych, w tym 600000 okazów włączonych jest do głównej kolekcji, a około 100000 kolejnych będzie włączone do głównego zbioru po wcześniejszym naukowym opracowaniu (zaetykietowaniu, oznaczeniu i przymontowaniu okazów do arkuszy zielnikowych). Zbiory botaniczne obejmuja także rośliny kopalne: ponad 10000 okazów znajdujacych się w kolekcji dydaktycznej Instytutu Botaniki, kolekcję owoców i szyszek: ok. 1000 eksponatów,

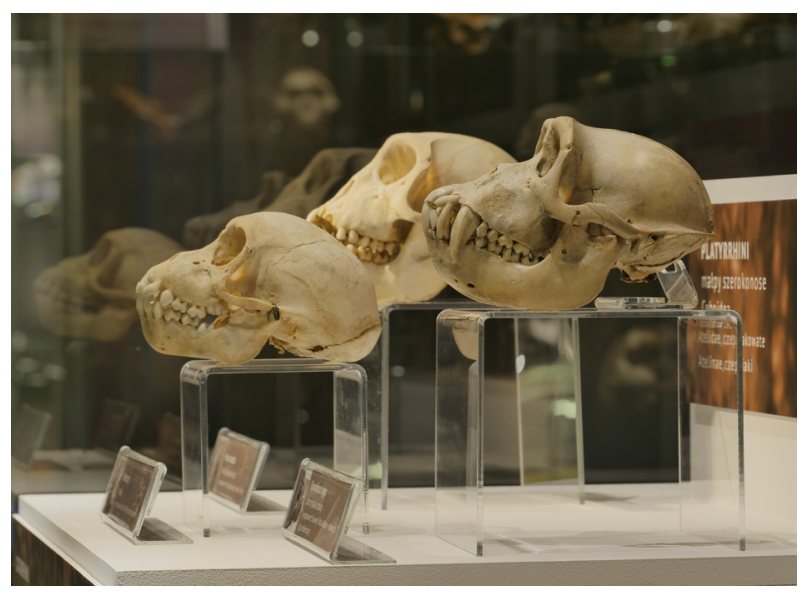

Ryc. 12. Czaszki małp (fot. A. Czekaj). 
oraz zielnik algologiczny liczacy około 1000 okazów. Warto tu nadmienić, że na podstawie umowy $z$ dnia 31.05.1968 r., ówczesny kierownik Katedry Systematyki i Geografii Roślin UJ prof. Jan Kornaś przekazał w depozyt Instytutowi Botaniki PAN 11745 torebek mchów i 1544 torebki watrobowców (KÖHLER 2001a). Opieczętowane były pieczątka o treści: „Herbarium Instituti et Horti Botanici Universitatis Jagellonicae Cracoviensis", a Instytut Botaniki PAN zobowiazał się do zapewnienia tym zbiorom należytej konserwacji i utrzymania oraz do ich udostępniania. Sa one nadal $\mathrm{w}$ depozycie w Zielniku Instytutu Botaniki im. W. Szafera PAN w Krakowie.

Największa część botanicznych kolekcji naukowych stanowia rośliny naczyniowe. Zbiór ten obejmuje wiele kolekcji pochodzacych $z$ różnych obszarów świata, jednak najliczniej reprezentowany jest zbiór okazów z terenu Polski i środkowej Europy, stanowiacy znacznie ponad połowę wszystkich okazów roślin. Był on gromadzony przez niemal wszystkich (byłych i obecnych) pracowników Instytutu Botaniki oraz wielu doktorantów i studentów wykonujących w nim swoje prace badawcze. Najstarsze w tej kolekcji okazy pochodza $z$ obszaru południowej i środkowej Europy. Sa umieszczone w pięciu, majacych formę książkowa, tomach zielnika, wykonanych w połowie XVII w. (PIEKIEEKO 1981, KöHLER 1999). Unikatowa i niewatpliwie bardzo cenna jest także kolekcja paprotników, zapoczatkowana przez prof. Mariana Raciborskiego, a następnie kontynuowana i rozwijana przez prof. Jana Kornasia. Obejmuje ona kilkadziesiąt tysięcy okazów $z$ całego świata, w tym kilkadziesiąt typów nomenklatorycznych gatunków opisanych na podstawie zdeponowanych w naszym Zielniku kolekcji tropikalnych paproci. Ponadto, prof. Jan Kornaś wraz z żona, prof. Anna Medwecka-Kornaś, zgromadzili także liczne zbiory gatunków afrykańskich. Okazy kolekcjonowane były w czasie wypraw badawczych lub podarowane prof. Janowi Kornasiowi m.in. przez Adama Starzeńskiego, Kazimierza A. Nowaka czy Stanisława Lisowskiego. $Z$ obszarów neotropikalnych przechowywanych jest kilka kolekcji, w tym dwie najcenniejsze, zebrane $z$ południowej i środkowej Ameryki w połowie XIX w. przez J. Warszewicza (ponad 600 arkuszy) i Konstantego Jelskiego (około 300 arkuszy). Zawieraja one wiele okazów typowych, na podstawie których zostały opisane gatunki nowe dla nauki. Stosunkowo licznie reprezentowane sa kolekcje roślin azjatyckich (obejmujace łącznie kilkadziesiąt tysięcy okazów). Zgromadzone zostały podczas wypraw naukowych prowadzonych m.in. przez: Mariana Raciborskiego (Indonezja - Jawa),

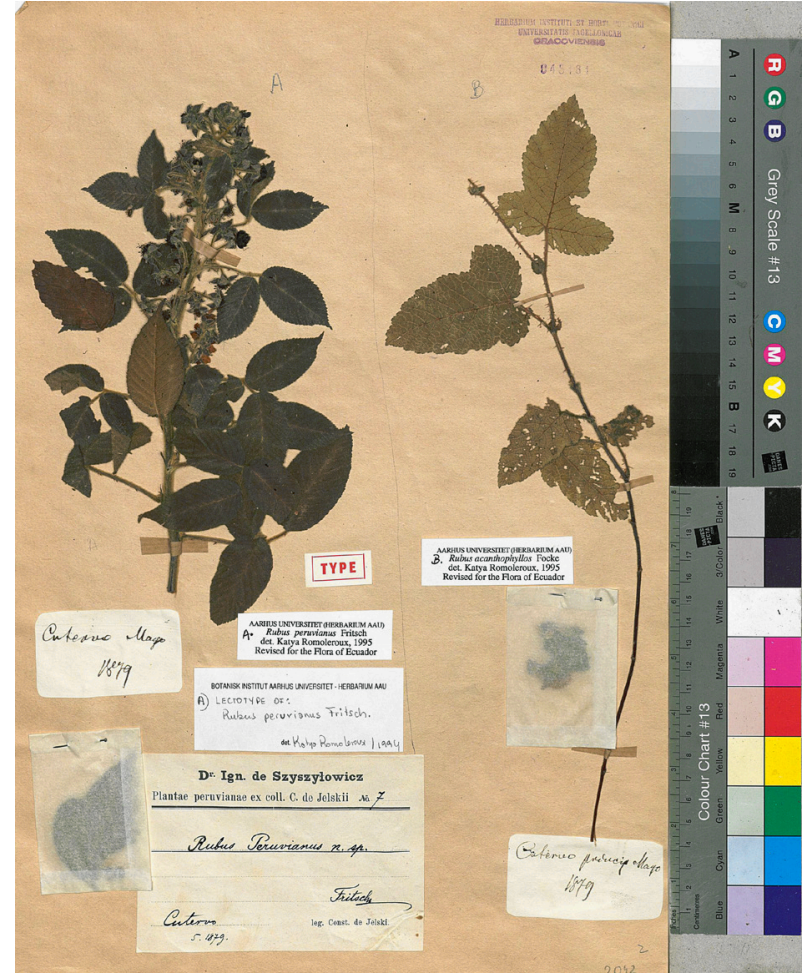

Ryc. 13. Rubus peruvianus Fritsch. z Peru, lektotyp gatunku (KRA 45181 A) (fot. M. Nobis).

Jana Kornasia (Wietnam), Annę Pacynę (Mongolia), Janusza Wojtusiaka (Afganistan), Adama Zająca (Irak), Marcina Nobisa (Tadżykistan, Kirgistan, Kazachstan, Rosja, Chiny, Uzbekistan, Gruzja) i Marię Zając (Kaukaz). Stosunkowo liczne zbiory, ponad 10000 arkuszy roślin naczyniowych, zostały zebrane w ostatnim czasie przez Adama Zająca, Marię Zając, Bogdana Zemanka i Danutę Zdebską z obszaru basenu Morza Śródziemnego. Do ważnych kolekcji w Herbarium należa również zbiory: Feliksa Berdaua (z Europy), Jana Kornasia i Anny Medweckiej-Kornaś (z Europy, Ameryki Północnej i Ameryki Południowej), Bogumiła Pawłowskiego (z gór środkowej i południowej Europy), Antoniego Rehmana (z Karpat), Adama Starzeńskiego (z Afryki), Aleksandra Ślendzińskiego (z Europy), Jana Walasa (z Europy) i Eustachego Wołoszczaka (z Karpat). W zielniku mszaków, do najważniejszych należa zbiory: Marii Olech (z Antarktyki, Arktyki - ze Spitsbergenu), Mariana Raciborskiego ( $z$ Jawy i okolicznych wysp), Bronisława Szafrana (z Europy), Antoniego Żmudy (z Europy) oraz Marty Mierzeńskiej ( $z$ obszaru Karpat). W zielniku grzybów największymi sa kolekcje: Barbary Gumińskiej (z Polski) i Mariana Raciborskiego ( $z$ Jawy i okolicznych wysp). Zielnik porostów obejmuje przede wszystkim porosty zebrane podczas badań naukowych prowadzonych przez pracowników Instytutu, 


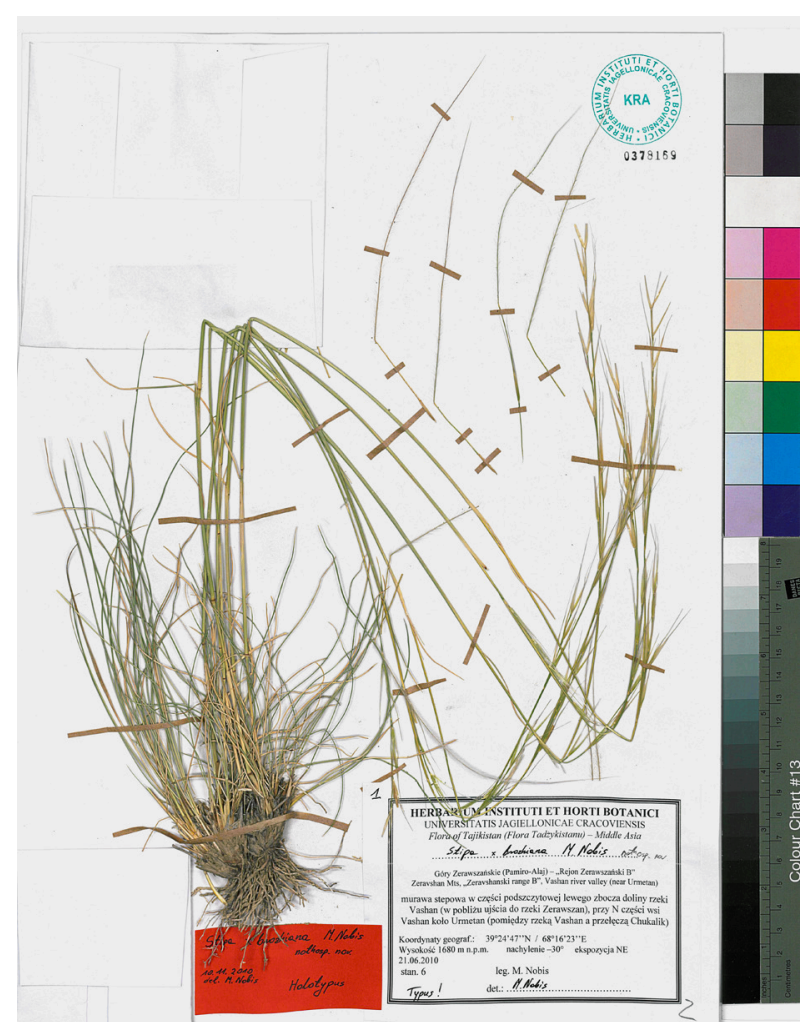

Ryc. 14. Stipa $\times$ brozhiana M. Nobis $z$ Tadżykistanu, holotyp gatunku (KRA 378169) (fot. M. Nobis).

doktorantów i studentów, w różnych obszarach Polski, a ponadto zbiór Marii Olech z Ziemi Ognistej w Południowej Ameryce, zbiór M. Olech i Eugeniusza Dubiela z Arktyki - ze Spitsbergenu, R. Wilczka z Grenlandii oraz M. Olech $z$ Islandii. Zbiór prof. Marii Olech $z$ Antarktyki jest największy w Polsce $\mathrm{i}$ jednocześnie jest to jeden $z$ najcenniejszych zielników na świecie. Zawiera on także wiele typów nomenklatorycznych nowo opisanych taksonów. Osobna część zajmują kolekcje algologiczne, głównie XIX-wiecznych wydawnictw zielnikowych (KÖHLER 1999, 2001a). Warto nadmienić, że w kolekcjach niemal wszystkich wyżej wymienionych grup systematycznych, znajdują się okazy typowe, na podstawie których opisanych zostało wiele nowych dla wiedzy taksonów. Liczbę wszystkich okazów typowych (arkuszy, kopert lub pudełek) znajdujacych się w kolekcji KRA (w tym holotypów, izotypów, paratypów, syntypów, lektotypów), można szacować na kilkaset (Ryc. 10, 13, 14).

\section{KOLEKCJE ZOOLOGICZNE}

Najwięcej okazów zoologicznych znajduje się w kolekcjach działu zoologicznego Centrum Edukacji Przyrodniczej Uniwersytetu Jagiellońskiego (CEP). Wiele $z$ nich pochodzi $z$ okresu funkcjonowania Gabinetu Historii
Naturalnej założonego w 1782 r., a liczne można obejrzeć obecnie w zoologicznej części ekspozycji. Zbiory w CEP sa prezentowane w ramach ekspozycji stałej i deponowane w przestrzeniach magazynowych. Ze względu na charakter i przeznaczenie kolekcji zoologicznych, można wyróżnić okazy ekspozycyjne i dydaktyczne oraz zbiory naukowe.

Okazy ekspozycyjne obejmuja preparaty suche oraz mokre i maja przeważnie charakter historyczny. Reprezentuja przedstawicieli większości typów organizmów występujących współcześnie na Ziemi. Najwięcej jest stawonogów, zdominowanych tu przez owady, pajęczaki i skorupiaki. Liczne są też mięczaki i kręgowce, a spośród nich: ryby, gady, ptaki i ssaki. Wśród eksponowanych okazów jest wiele gatunków obecnie skrajnie zagrożonych, rzadkich i wyjątkowo interesujacych pod względem biologicznym, np.: Strigops habroptila (papuga kakapo) (Ryc. 8), duży, a zarazem najcięższy gatunek papugi na świecie, jedyny nielotny ptak rodziny kakapowatych (Strigopidae) endemicznej dla Nowej Zelandii; czaszka krowy morskiej, Hydrodamalis gigas, wymarłego, olbrzymiego (osobniki dorosłe $z$ XVIII w. ważyły od 8 do 20 ton, osiągając do $9 \mathrm{~m}$ długości) gatunku ssaka $z$ rodziny diugoniowatych (Dugongidae), który został odkryty przez Europejczyków w 1741 r., kiedy spotykano go tylko wokół Wysp Komandorskich na Morzu Beringa między Alaska a Rosja (Ryc. 3), oraz żółwie $\mathrm{z}$ Galapagos $\mathrm{z}$ rodzaju Chelonoidis, a także Sphenodon sp. (hatteria, tuatara lub łupkozab) (Ryc. 7). Ten ostatni rodzaj reprezentuja gady $z$ rodziny hatteriowatych (Sphenodontidae) występujace endemicznie na Nowej Zelandii. Choć $z$ wyglądu przypomina najbardziej jaszczurkę, to w rzeczywistości reprezentuje sfenodonty, odrębna linię ewolucyjna lepidozaurów, a hatterie sa jedynymi współczesnymi przedstawicielami tej grupy. Najbliżej sa one spokrewnione $z$ łuskonośnymi (Squamata) obejmujacymi jaszczurki, amfisbeny i węże. Stąd hatteria interesuje naukowców zajmujacych się ewolucją jaszczurek i węży oraz rekonstruujących wygląd i behawior najwcześniejszych diapsydów. Wiele prezentowanych okazów należy do kolekcji, których historie sa ściśle powiazane $z$ dziejami Uniwersytetu Jagiellońskiego i aktywnościa wielu znanych przyrodników, np. kolekcja krabów i ryb raf koralowych, czy kolekcja ptaków z Brazylii pochodząca $z$ okresu zaboru austriackiego. Niezwykle cenny jest również zbiór muszli mięczaków, szacowany na kilkanaście tysięcy okazów, który Uniwersytetowi został przekazany przez Bolesława Raczkę, kolekcjonera amatora, który poświęcił niemal całe swoje życie na podróże zwiazane ze swoją pasją. 
Okazy dydaktyczne obejmuja modele, preparaty anatomiczne różnych narządów i układów zwierząt oraz przekroje, a także wiele innych materiałów i narzędzi wykorzystywanych dawniej $\mathrm{w}$ procesie kształcenia studentów biologii, choć wiele $z$ nich również obecnie stanowi ważna część procesu dydaktycznego. Większość z tych okazów ma jednak tylko charakter historyczny i nie jest już wykorzystywana we współczesnych programach studiów.

Największą część zoologicznych zbiorów naukowych stanowia owady, w tym głównie Lepidoptera liczace około 600000 okazów. Zbiór ten reprezentuje wszystkie rodziny motyli pochodzacych $z$ wielu krain zoogeograficznych: Neotropik - 200000 okazów; Afrotropik - 180 000; Palearktyka - 120 000, w tym Polska - 35000 oraz Orient i Australia - 55000 i Nearktyka 10000 okazów. Obecnie jest to największy i najcenniejszy pod względem naukowym zbiór motyli $\mathrm{w}$ Polsce $\mathrm{i}$ jeden $\mathrm{z}$ najcenniejszych na świecie, w szczególności jeśli chodzi o faunę Andów i tropikalnej Afryki. Od szeregu lat do końca 2020 r. kolekcja lepideptorologiczna zwiększała się o ok. 20000 okazów rocznie. We wzbogacaniu zbiorów motyli w UJ uczestniczyły pokolenia pracowników naukowych, entomologów amatorów i kolekcjonerów. Gromadzono je podczas realizacji wielu różnych projektów badawczych oraz wypraw naukowych pracowników, doktorantów i studentów UJ (np. wyprawy do byłego ZSRR). Były też przekazywane przez kolekcjonerów prywatnych. Najstarsze kolekcje Lepidoptera w UJ pochodza $z$ początku XIX w. i zostały nabyte od Imre Frivaldszkyego, znanego przyrodnika węgierskiego. W połowie XIX w. do UJ przekazano bardzo cenny zbiór motyli świata (ok. 1500 okazów) Felicjana Sypniewskiego, polskiego entomologa $z$ Poznania. $Z$ pierwszej połowy $\mathrm{XX}$ w. warto wspomnieć o motylach ofiarowanych przez prof. Michała Siedleckiego, które pochodza $z$ Indonezji, prof. Czesława Bieżanko - $z$ Brazylii oraz Feliksa Woytkowskiego - z Peru. Największe kolekcje motyli zostały przekazane przez prof. Romana Wojtusiaka (motyle egzotyczne) i jego syna prof. Janusza Wojtusiaka (około 50000 okazów z Nigerii i Afganistanu) oraz dr hab. Tomasza Pyrcza [w sumie około 100000 okazów z Afryki, Azji, Europy i Ameryki Południowej (Ryc. 15), zbieranych na przestrzeni ostatnich 30 lat], a także pana Pierrea Boyer, który kilkanaście lat temu ofiarował UJ swoją prywatna kolekcję (ok. 120000 okazów z całego świata), jedną $z$ największych kolekcji prywatnych we Francji. Ponadto, zbiory lepideptorologiczne obejmuja również kolekcje dr Leszka Pawlaka (ok. 20000 egzempla-

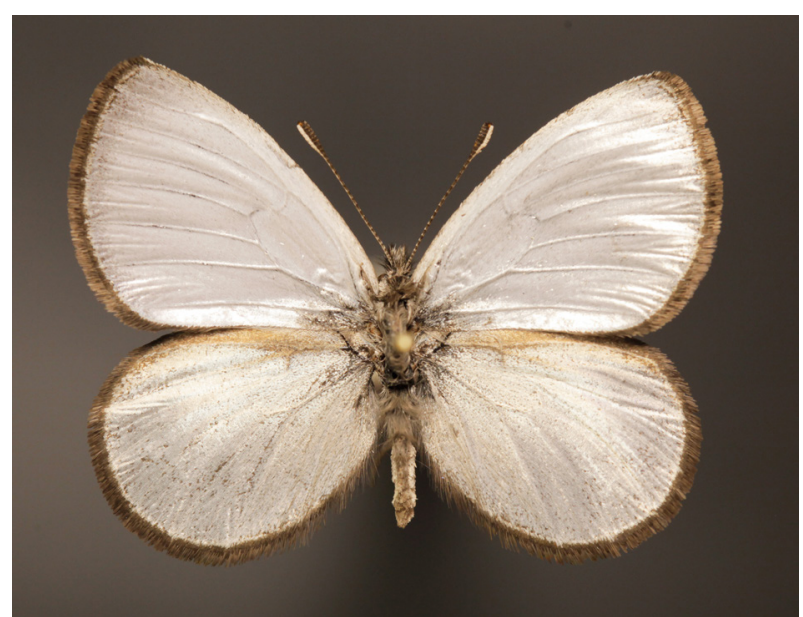

Ryc. 15. Argyrophorus idealis Pyrcz \& Cerdeńa, 2019, gatunek oczennicy (Satyrinae) z wysokich Andów Środkowego Peru występujący na wysokości około $4000 \mathrm{~m}$ npm, jeden $z$ ok. 450 gatunków i podgatunków motyli dziennych opisanych przez J. Wojtusiaka, T. Pyrcza oraz współpracowników w Muzeum Zoologicznym UJ, których typy opisowe znajduja się obecnie w CEP UJ (fot. T. Pyrcz).

rzy), inż. Piotra Kowalskiego (ok. 5 000), p. Waldemara Staszela (ok. 5 000), dr Wojciecha Kudły i prof. Jarosława Buszko (motyle Polski, głównie Microlepidoptera). Niezwykle ważną częścia zbioru sa okazy pozyskiwane przez międzynarodowa grupe badawcza pod kierownictwem dr Roberta Tropek $z$ Pragi i dr Szabolcs Safian z Sopron (ok. 150000 z Kamerunu) oraz Artura Jasińskiego (30 000 z Andów). Pod koniec 2020 r. UJ został obdarowany kolekcja pana Raoula Cagnon, zawierająca ok. 25000 okazów z Francji, Azji i Madagaskaru. Wiele bezcennych motyli zostało przekazanych również przez zaprzyjaźnione muzea, w tym Muzeum Historii Naturalnej Węgierskiej Akadami Nauk w Budapeszcie oraz Muzeum Senckenberg w Dreźnie. Okazy motyli sa ułożone porządku systematycznym w obrębie poszczególnych krain zoogeograficznych świata. Warto tu zaznaczyć, że wiele tysięcy $z$ nich ma niezwykłą i bezcenną wartość naukowa, gdyż sa to okazy typowe, czyli tzw. typy nomenklatoryczne gatunków (holotypy i paratypy), będace podstawowym wzorcem taksonów nowo opisanych dla nauki. Motyle znajdujace się w zbiorach UJ były tematem kilkuset prac naukowych i licznych prac dyplomowych, zarówno autorów polskich, jak i $z$ całego świata. Pozostałe kolekcje entomologiczne zawieraja okazy reprezentujace inne rzędy owadów. Duży zbiór sieciarek (Neuroptera) i muchówek (Diptera) z Afryki Południowej został ofiarowany do badań naukowych przez dr Roberta Tropka, lidera międzynarodowego 


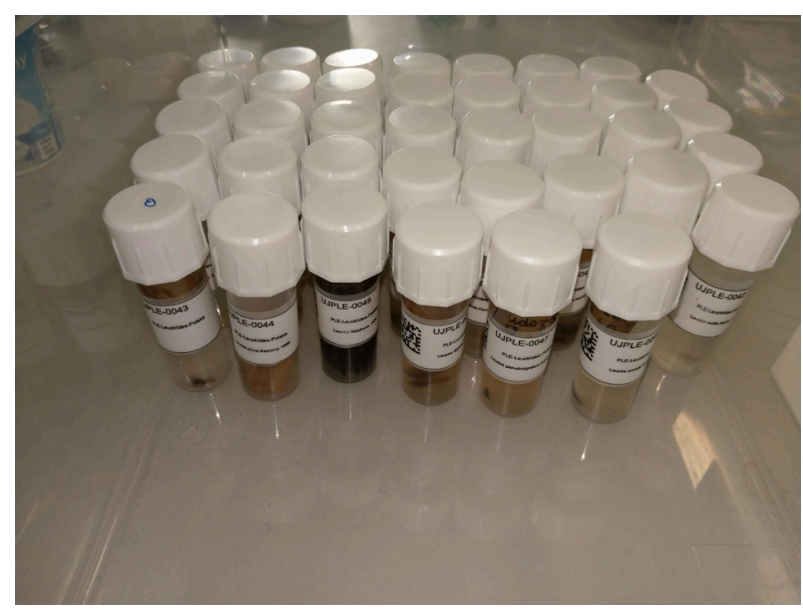

Ryc. 16. Zbiory widelnic (Plecoptera) w INoŚ UJ, zgromadzone przez prof. R. Sowę (fot. W. Fiałkowski).

projektu badawczego. Liczne okazy chrzaszczy (Coleoptera) i pluskwiaków (Hemiptera) zostały zebrane przez prof. Maksymiliana Siłę Nowickiego w XIX w. oraz prof. Janusza Wojtusiaka, dr hab. Tomasza Pyrcza i inż. Piotra Kowalskiego w późniejszych latach. Gablote reprezentujaca chrzaszcze krajowe $z$ nadrodziny ryjkowców (Curculionoidea) przekazali mgr Emilia Knutelska wraz $z$ mężem dr. hab. Stanisławem Knutelskim. Wśród stawonogów (Arthropoda) jest też kolekcja roztoczy (Acarina) opracowana przez profesorów Wiktora Micherdzińskiego i Wojciecha Witalińskiego, a spośród innych bezkręgowców pokrewnych stawonogom jest również zbiór typów opisowych niesporczaków (Tardigrada), przekazany przez dr. hab. Łukasza Michalczyka.

Niezwykle cenna kolekcję stanowia również zbiory ryb $z$ Antarktydy i Jeziora Bajkał opracowane przez prof. Michała Jakubowskiego, a także okazy skorupiaków i innych bezkręgowców wodnych zebrane przez prof. Benedykta Dybowskiego, głównie $z$ Jeziora Bajkał podczas jego zesłania w 1865 r. na Syberię za jego konspiracyjna działalność patriotyczną. Wraz ze współpracownikiem Wiktorem Godlewskim, również zesłańcem za udział $\mathrm{w}$ powstaniu styczniowym, $\mathrm{w}$ bardzo trudnych warunkach, często przy 40-stopniowym mrozie, $z$ pomoca własnoręcznie sporzadzonych narzędzi, badali faunę tego jeziora, uważanego wcześniej za ubogie pod tym względem. Publikacje Dybowskiego, potwierdzone materiałami dowodowymi, pozwoliły lepiej poznać różnorodność biotyczna i pochodzenie fauny Bajkału. Efektem tych badań było odkrycie przez Dybowskiego wielu nowych dla nauki taksonów zwierzat, m.in. 116 nowych gatunków skorupiaków $z$ rzędu obunogów (Amphipoda) i 6 nowych

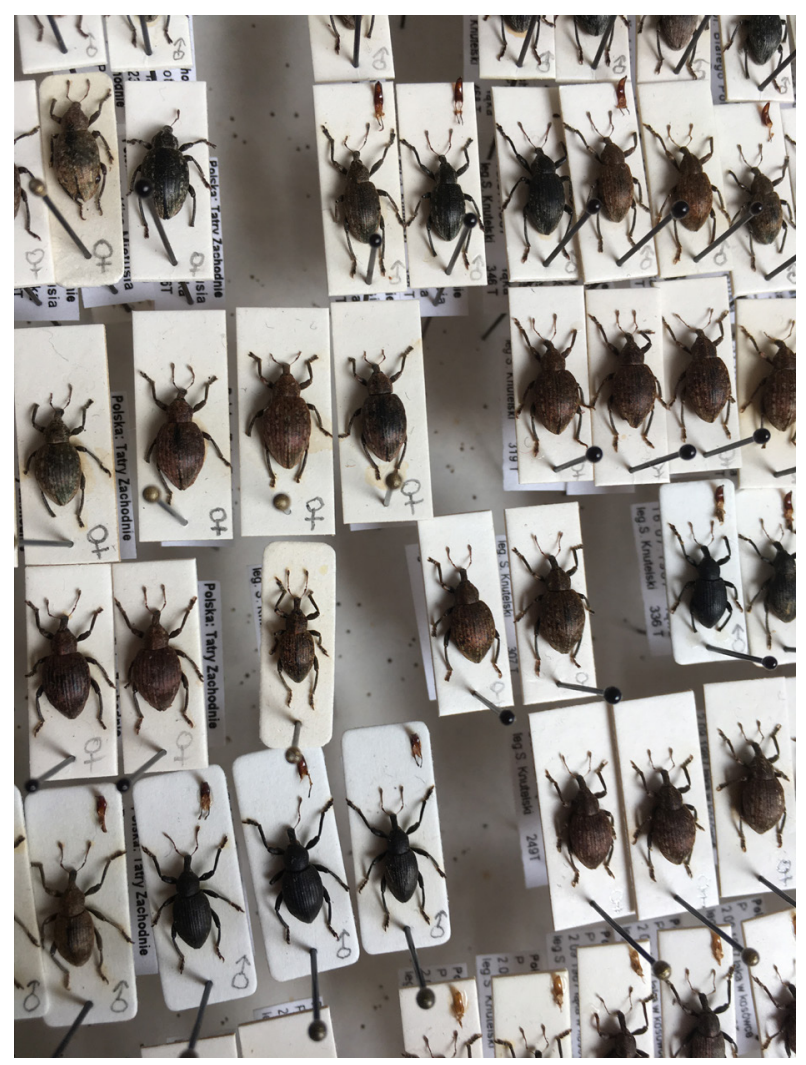

Ryc. 17. Ryjkowce (Curculionoidea) z kolekcji E. i S. Knutelskich (IZiBB UJ) (fot. S. Knutelski).

gatunków ryb. Na podstawie materiałów bajkalskich zebranych przez Benedykta, jego brat Władysław Dybowski opisał 88 gatunków mięczaków i 9 gatunków gąbek nowych dla nauki, a inne zbiory tego znakomitego przyrodnika i lekarza opracowali profesorowie: Grube $z$ Berlina, Józef Nusbaum ze Lwowa i Roman Gutwiński z Krakowa.

Ze względu na szeroki zakres systematyczny i zoogeograficzny zbiorów w CEP, wiele $z$ nich wymaga naukowego opracowania, uporządkowania, inwentaryzacji, digitalizacji i konserwacji. Jest to proces ciagły, również generowany przez ustawicznie zmieniajacy się stan poznania oraz nowe odkrycia.

W Instytucie Nauk o Środowisku UJ znajduja się zbiory jętek i widelnic zgromadzone przez prof. Ryszarda Sowę (Ryc. 16), wybitnego badacza tych rzędów owadów. Obejmuja one zakonserwowane w alkoholu okazy nimf (larwy o przeobrażeniu niezupełnym) i form dorosłych (imagines). Większość została zebrana osobiście przez prof. Sowę, ale sa też okazy przekazane mu przez kolegów $\mathrm{z}$ innych ośrodków w Europie. W tym Instytucie znajduja się także rozproszone kolekcje różnych grup owadów, pochodzące z badań ekologicznych. Niestety, z powodu przedwczesnej śmierci prof. Sowy większość tych zbiorów nie jest poprawnie skatalogo- 
wana. Ich dokładne opracowanie wymagać będzie dużego nakładu pracy i obecnie realizowany projekt IMBIO może w tym wydatnie pomóc.

W Instytucie Zoologii i Badań Biomedycznych przechowywane sa zbiory Emilii i Stanisława Knutelskich (Ryc. 17), gromadzone podczas wieloletnich badań faunistycznych tego drugiego, czy ich prywatnych wyjazdów terenowych. Sa to głównie ryjkowce (Curculionoidea) i inne grupy systematyczne chrzaszczy zebrane w Karpatach (Rumunia, Ukraina, Polska, Słowacja), Sudetach, Pirenejach (Francja), Alpach (Słowenia, Austria, Włochy), na Bałkanach (Bułgaria, Grecja, Chorwacja, Czarnogóra) oraz w innych rejonach kraju, czy Europy (Anglia, Belgia, Czechy, Francja, Słowacja, Wegry) lub pochodzące $z$ wymian okazów pomiędzy entomologami $z$ różnych krajów świata. Pewne okazy zostały im ofiarowane przez profesorów Szczepana Bilińskiego i Zbigniewa Witkowskiego. Wiele zebranych przez Knutelskich owadów lub innych bezkręgowców zostało w postaci luźnej lub preparatów ofiarowane na rozmaite zajęcia dydaktyczne studentów biologii.

W ramach projektu „Integracja i mobilizacja danych o różnorodności biotycznej Eukaryota w zasobach polskich instytucji naukowych" (IMBIO) Uniwersytet Jagielloński zadeklarował do digitalizacji łacznie 381560 okazów organizmów jądrowych (Eukaryota), w tym 244000 okazów z kolekcji botanicznych i 137560 okazów ze zbiorów entomologicznych. Ponadto udostępniono ponad 12500 rekordów $z$ baz danych ryjkowców (Curculionoidea) oraz wiele danych $z$ systemu informacji geograficznej (GIS) do integracji rekordów danych digitalizowanych organizmów w ramach tego projektu.

\section{PODZIEKKOWANIA}

Składamy serdeczne podziękowania panu mgr. Arturowi Czekajowi z CEP UJ za ofiarowanie swoich zdjęć do niniejszej publikacji oraz anonimowemu recenzentowi, a także Kolegium Redakcyjnemu za konstruktywne uwagi i sugestie, które pomogły w podniesieniu jakości tego opracowania.

\section{Streszczenie}

Przedstawiono historię powstawania naukowych kolekcji okazów przyrodniczych Uniwersytetu Jagiellońskiego przechowywanych obecnie na Wydziale Biologii (Instytut Botaniki, Instytut Nauk o Srodowisku, Instytut Zoologii i Badań Biomedycznych) i w Centrum Edukacji Przyrodniczej oraz obecny stan ich poznania, a także wkład przyrodników mających największy udział w ich tworzeniu i powiększaniu. Najstarsze kolekcje pochodza z przełomu XV i XVI w. Zbiory naukowe w UJ stanowiły i stanowia podstawę badań oraz rozwoju nauki i edukacji, nie tylko w Polsce. Ze względu na szeroki zakres systematyczny i biogeograficzny zgromadzonych kolekcji, wiele $z$ nich wymaga naukowego opracowania, uporząkowania, inwentaryzacji, digitalizacji oraz konserwacji. Jest to proces ciagły, generowany także przez ustawicznie zmieniajacy się stan poznania oraz nowe odkrycia. Obecnie zbiory botaniczne i entomologiczne UJ sa w trakcie digitalizacji w ramach projektu „Integracja i mobilizacja danych o różnorodności biotycznej Eukaryota w zasobach polskich instytucji naukowych" (IMBIO).

\section{LITERATURA}

BEIERSDORF K., 1992. Historia Muzeum Zooogicznego Uniwersytetu Jagiellońskiego. Zeszyty Nauk. UJ, Prace Zool. 1011, 61-74.

BEIERSDORF K., SMAGOWICZ K., 1984. Muzeum Zoologiczne Uniwersytetu Jagiellońskiego. [W:] Zbiory zoologiczne $w$ polskich instytucjach pañstwowych. Praca zbiorowa pod redakcja Józefa Razowskiego. Razowski J. (red.). Przegl. Zool., Muzealnictwo Zoologiczne, 316-319.

GŁĄB H., Kosydarski A., 1984. Muzeum Antroplogiczne Uniwersytetu Jagiellońskiego. [W:] Zbiory zoologiczne $w$ polskich instytucjach państwowych. Praca zbiorowa pod redakcja Józefa Razowskiego. Razowski J. (red.). Przegl. Zool., Muzealnictwo Zoologiczne, 315-316.

JURA CZ., 1992. Historia zoologii $w$ Krakowie. Zesz. Nauk. UJ, Pr. Zool. 37, 21-32.

KÖHLER P., 1991. Dziewiętnastowieczne pomoce naukowe $w$ zbiorach Muzeum Ogrodu Botanicznego Uniwersytetu Jagiellońskiego. Wiad. Bot., Muzea, archiwalia, zbiory 35, 96-99.

KÖHLER P., 1999. Historia Zielnika Instytutu Botaniki Uniwersytetu Jagiellońskiego (KRA) w latach 1780-1910. Kwartalnik Historii Nauki i Techniki 44, 7-60.

KÖHLER P., 2001a (wyd. 2002). Historia Zielnika Instytutu Botaniki Uniwersytetu Jagiellońskiego (KRA) w latach 1910-2000. Kwartalnik Historii Nauki i Techniki 46, 77-104.

KÖHLER P., 2001b. History of the Jagiellonian University Herbarium (KRA), Cracow, Poland. Taxon 50, 943-945.

KÖHLER P., ZEMANEK A., 2018. Marian Raciborski - założyciel Instytutu Botaniki UJ. W stulecie śmierci. Alma Mater 199, 98.

PIEKIEŁKO A., 1981. Dwa osiemnastowieczne zielniki ze zbiorów Instytutu Botaniki Uniwersytetu Jagiellońskiego. Zakł. Nar. im. Ossolińskich Wrocław-Warszawa-Kraków-Gdańsk.

RADWAŃSKA-PARYSKA Z, PARYSKI W. H., 1995. Wielka encyklopedia tatrzańska. Wydawnictwo Górskie, Poronin.

RosTAFIŃSKI J., 1900. Antibolomenum (Antidotarium, Antibolarium) Benedicti Parthi, powst. 1472. [W:] Symbola ad historiam naturalem medii aevi, Kraków. RostAFIŃSKI J. (red.), rękopis: Biblioteka Kapitulna Krakowa nr 225.

ZAPALSKI M. K., 2005. A new species of Tabulata from the Emsian of the Holy Cross Mts., Poland. N. Jb. GeoI. Paliiont. Mh. 2005, 248256. 
KOSMOS Vol. 70, 2, 273-289, 2021

\section{Knutelski Staniseaw ${ }^{1}$, Nobis Marcin ${ }^{2}$, Pyrcz Tomasz ${ }^{1}$, FiatKowski Wojciech ${ }^{3}$}

${ }^{1}$ Institute of Zoology and Biomedical Research, Jagiellonian University, 9 Gronostajowa Str., Kraków, ${ }^{2}$ Institute of Botany, Jagiellonian University, 3 Gronostajowa Str., Kraków, ${ }^{3}$ Institute of Environmental Sciences, Jagiellonian University, 7 Gronostajowa Str., Kraków, E-mail:s.knutelski@uj.edu.pl

\section{RESOURCES OF INFORMATION ON BIODIVERSITY OF EUKARYOTA IN THE NATURAL HISTORY COLLECTIONS OF THE JAGIELLON UNIVERSITY}

\section{Summary}

In this article, the history of the formation of scientific collections of nature specimens of the Jagiellonian University, currently stored at the Faculty of Biology (Institute of Botany, Institute of Environmental Sciences, Institute of Zoology and Biomedical Research) and the Nature Education Center is presented, as well as the current state of their knowledge, and the contributions of naturalists who have the greatest share in their creation and magnifying. The oldest collections come from the turn of the 15th and 16th centuries. Scientific collections of the Jagiellonian University have been the basis for research and development of science and education, not only in Poland. Due to the wide systematic and biogeographic scope of the gathered collections, many of them require scientific elaboration, ordering, inventorying, digitization and conservation. It is a continuous process, also generated by the constantly changing state of knowledge and new discoveries. Currently, the botanical and entomological collections of the Jagiellonian University are being digitized as part of the "Integration and mobilization of data on the biodiversity of Eukaryota in the resources of Polish scientific institutions (IMBIO) project.

Keywords: biodiversity, Eukaryota, information resources, Jagiellonian University, natural history collection 